\title{
Do pharmacokinetic polymorphisms explain treatment failure in high-risk patients with neuroblastoma?
}

\author{
Francesco Bellanti • Bertil Kågedal • \\ Oscar Della Pasqua
}

Received: 21 November 2010 / Accepted: 27 November 2010/Published online: 2 February 2011

(C) The Author(s) 2011. This article is published with open access at Springerlink.com

\begin{abstract}
Purpose Neuroblastoma is the most common extracranial solid tumour in childhood. It accounts for $15 \%$ of all paediatric oncology deaths. In the last few decades, improvement in treatment outcome for high-risk patients has not occurred, with an overall survival rate $<30-40 \%$. Many reasons may account for such a low survival rate. The aim of this review is to evaluate whether pharmacogenetic factors can explain treatment failure in neuroblastoma.

Methods A literature search based on PubMed's database Medical Subject Headings (MeSH) was performed to retrieve all pertinent publications on current treatment options and new classes of drugs under investigation. One hundred and fifty-eight articles wer reviewed, and relevant data were extracted and summarised.

Results and conclusions Few of the large number of polymorphisms identified thus far showed an effect on pharmacokinetics that could be considered clinically relevant. Despite their clinical relevance, none of the single nucleotide polymorphisms (SNPs) investigated can explain treatment failure. These findings seem to reflect the clinical context in which
\end{abstract}

F. Bellanti · O. Della Pasqua $(\triangle)$

Division of Pharmacology,

Leiden/Amsterdam Center for Drug Research,

P.O. Box 9502, 2300 RA Leiden, The Netherlands

e-mail: odp72514@gsk.com

O. Della Pasqua

Clinical Pharmacology \& Discovery Medicine, GlaxoSmithKline,

Stockley Park, UK

B. Kågedal

Division of Clinical Chemistry, Department of Clinical and

Experimental Medicine, Linköping University,

58185 Linköping, Sweden anti-tumour drugs are used, i.e. in combination with multimodal therapy. In addition, many pharmacogenetic studies did not assess (differences in) drug exposure, which could contribute to explaining pharmacogenetic associations. Furthermore, it remains unclear whether the significant activity of new drugs on different neuroblastoma cell lines translates into clinical efficacy, irrespective of resistance or myelocytomatosis viral related oncogene, neuroblastoma derived (MYCN) amplification. Elucidation of the clinical role of pharmacogenetic factors in the treatment of neuroblastoma demands an integrated pharmacokinetic-pharmacodynamic approach to the analysis of treatment response data.

Keywords Neuroblastoma · Pharmacogenetics . Pharmacokinetics $\cdot$ Cytotoxic drugs $\cdot$ Modelling \& simulation P PKPD modelling

\section{Introduction}

Neuroblastoma

Neuroblastoma (NB) is the most common extracranial solid tumour in childhood and belongs to the group of "small blue round cells" neoplasms. It accounts for $15 \%$ of all paediatric oncology deaths [1-3]. Its incidence peaks at age $0-4$ years, and $<5 \%$ of patients are older than 10 years of age [2]. It is a neuroendocrine tumour tightly connected to the sympathetic nervous system (SNS). Given that it originates from the primitive neuroepithelial cells of the neural crest, it can develop anywhere in the SNS. Fifty percent of primary tumours arise in the adrenal medulla, but other common sites are neck, chest, abdomen, and pelvis. At diagnosis, in most cases, neuroblastoma has already metastasised, usually to liver, bone, bone marrow, lymph 
nodes, and skin [1-3]. Despite its prevalence and invasiveness, the aetiology of neuroblastoma is still poorly understood. Few causative factors have been identified: familiar forms are rare (about 1\%); there is no clear genetic predisposition, and presumably tumorigenesis may require alterations in more than one gene. The hallmark of the tumour is heterogeneity; its behaviour can vary from a localised tumour, easy to resect with surgery, to a metastatic progressive one, with high resistance and poor outcome; strikingly, in $5 \%$ of cases, it manifests a spontaneous regression. Prognosis, in the same manner, ranges from overall survival (OS) to high fatality risk. Because of the tumour heterogeneity, biomarkers have been used to select the appropriate treatment schedule according to a risk-group classification. Myc myelocytomatosis viral related oncogene, neuroblastoma derived (MYCN) amplification, chromosomal loss (1p) or gain (17q), DNA index (near diploid), age $>18$ months, and International Neuroblastoma Staging System (INSS) stages III and IV, are all predictors of poor prognosis and disease malignancy [1-7]. As with MYCN, many other biomarkers have been studied to define phenotype (disease severity) and stratify patients, such as e.g. the tyrosine kinase (Trk) family of neurotrophin receptors, which are important regulators of survival, growth, and differentiation of normal neuronal cells; high expression of TrkB and TrkA III is associated with MYCN amplification and poor outcome, whereas high expression of TrkA is associated with a favourable status. In spite of these data, to date only the amplification of the oncogene MYCN can be considered as an independent marker of tumour status and treatment outcome $[1,2]$. The current risk-group classification of the disease and the corresponding treatment protocols have therefore been defined according to tumour behaviour and biomarker prediction.

Although in the last 20 years this approach substantially improved treatment outcome for low- and intermediate-risk patients, to date, there has been little improvement in the high-risk patient group. Despite intensive polytherapy, high-risk patients still only have an OS rate of $30-40 \%$ $[1,3]$. There may be several reasons for the low OS rate. Considering that important associations have been demonstrated between pharmacogenetics and efficacy in different solid tumours (e.g., increased efficacy of Herceptin in the treatment of human epidermal growth factor receptor 2 (HER2)-positive breast cancers with benefits in terms of diseasefree (DFS) and OS [8-10]), the aim of this review was to explore the role of pharmacogenetics in the treatment of neuroblastoma. The main question to be addressed is whether pharmacogenetic differences can (partly) explain treatment failure. In addition, we propose the use of modelbased interventions, such as different dosing algorithms, to improve the outcome of therapy and the safety profile of current and novel drugs in high-risk patients.
Pharmacogenetics

In the context of our review, the term pharmacogenetics is considered as defined by the International Conference of Harmonisation of Technical Requirements for Registration of Pharmaceuticals for Human Use (ICH), even if other definitions have been reported in the scientific literature. According to the proposed ICH definitions, pharmacogenomics is the investigation of variations of DNA and RNA characteristics as related to drug response. Pharmacogenetics is a subset of pharmacogenomics and is defined as the influence of variations in DNA sequence on drug response [8]. Pharmacogenetics is a relatively new field of research, which aims to improve medical knowledge using DNA sequence information [11, 12].

Clinical research on prognostic, risk and covariate factors often assigns a privileged position to pharmacogenetics compared with other determinants of drug response. This approach often disregards the multivariate nature of the interaction between all relevant factors underlying treatment response, which may cause biased analysis and misinterpretation of the findings. Too narrow a vision of the clinical factors contributing to variability reduces the opportunity to understand the true role of pharmacogenetics and to relate it to real-life applications. It is critical to realise that pharmacogenetics is only one of the many factors that can influence pharmacokinetics, pharmacodynamics and clinical response, and that these factors can interact with each other. This review represents an effort to answer the questions posed above 1) by evaluating the role of pharmacogenetics on the pharmacokinetics of cytotoxic drugs used in the treatment of neuroblastoma and 2) by highlighting the requirements to evaluate its role in new therapeutic interventions. In addition, suggestions are given for alternative therapeutic approaches, which can potentially reduce treatment failure.

\section{Methods}

Literature search on PubMed's database Medical Subject Headings (MeSH) was performed to retrieve relevant published data. The search method involved structured keywords and was divided into two phases.

In the first phase, attention was given to cytotoxic drugs currently used for the treatment of neuroblastoma. In the first step, the drug's generic name was associated to four general keywords: pharmacokinetics, pharmacogenetics, neuroblastoma, and leukaemia. Subsequently, the drug name was associated to specific elements of drug disposition. In the secon phase, new classes of drugs currently in clinical development were evaluated. The search involved retrieval of all publications related to the treatment of neuroblastoma, which focused on pharmacogenetics. In 
addition, pharmacokinetic data on the aforementioned drugs were retrieved from paediatric studies, and especially from studies of patients affected by neuroblastoma or leukaemia [13-59]. Conversely, pharmacogenetic data were gathered from any available study [60-123]. We decided to exclude references related to genetic variations in pharmacodynamics and disease.

A total of 158 articles and reviews were used for abstraction and extraction. Data on exposure, efficacy and toxicity were summarised using MS Excel spreadsheets. An overview of the findings and potential relevance of genetic variation is presented for both cytotoxic drugs (Tables 1, 2, and 3) and drugs under clinical investigation (Tables 4, 5, and 6).

\section{Results}

Cytotoxic drugs

The use of cytotoxic drugs in neuroblastoma treatment is considered as an adjuvant or add-on therapy to chemotherapy (CT), radiotherapy, surgical resection, stem-cell transplantation, and treatment of minimal residual disease (MRD) [3]. CT approaches used in low-, intermediate-, and high-risk patient groups present differences in terms of dosing regimens and drug associations. In high-risk patients, cytotoxic drugs are used in two different phases of treatment: first, during induction CT, which is aimed at metastasis control and primary tumour resection; and second, during myeloablative chemotherapy (or highdose CT) in association with stem-cell transplantation with the aim of consolidating induction CT and surgery [3]. Despite the various treatment approaches, high-risk groups have a very low OS rate $(30-40 \%)[1,3]$. To clarify whether or not genetic variants could explain the lack of response, the role of pharmacogenetics in influencing pharmacokinetics of six of the main cytotoxic drugs used in neuroblastoma treatment was evaluated. Without taking into account the nature of treatment as adjuvant therapy, it was found that only few single nucleotide polymorphisms (SNPs) show a relevant effect on pharmacokinetics. In agreement with our hypothesis, published results seem to confirm that an SNP must affect a key enzyme or pathway to translate genetic variation into clinically relevant differences. Tables 1,2 and 3 provide the summary of the findings. The most relevant polymorphisms evaluated are briefly described in the following paragraphs.

\section{Irinotecan}

To date UDP glucuronosyltransferase 1 family, polypeptide A1 (UGT1A1)*28 is the only SNP introduced in a label (US) among all cytotoxic drugs included in this review. It is noteworthy to emphasise that UGT1A is the main enzyme in controlling deactivation of 7-ethyl-10hydroxycamptothecin (SN-38), the active metabolite of irinotecan. The label of CAMPTOSAR (irinotecan hydrochloride injection) has been revised with the following pharmacogenetic information: patients homozygous for the UGT1A $1 * 28$, who undergo a single-agent treatment with irinotecan, have a higher exposure to the active metabolite and are at increased risk for neutropenia [8]. In fact, various publications seem to confirm higher exposure to SN-38 [85, 89, 90, 107-109, 115, 116, 119] and the increased risk for neutropenia [85, 100, 108, $113,115,117]$ in patients harbouring the UGT1A $1 * 28$ allele. On the same enzyme, another SNP showed a similar effect on SN-38 exposure. Studies on the UGT1A1*6, SNP expressed in Asian individuals also showed higher exposure to the active metabolite $[86,88,89,106,110]$ and an increased risk for neutropenia [86, 88, 89]. However, further studies are needed to assess the clinical value of UGT1A $1 * 6$.

\section{Vincristine}

According to Dennison et al. [60, 69], and Renbarger et al. [68], cytochrome P450 (CYP)3A4 and CYP3A5 play key roles in metabolising vincristine to its main metabolite (the secondary amine M1), with a 9- to 14-fold higher selectivity for CYP3A5. As mentioned earlier, polymorphisms affecting the primary metabolic pathway are required to influence the pharmacokinetic profile of a drug. Although in the study by Dennison et al. patients with a high expression of CYP3A5 (homozygous: *1/*1; heterozygous: $* 1 / * 3, * 1 / * 6$ ) showed lower exposure to vincristine, and patients with a low expression of the enzyme (homozygous: *3/*3; heterozygous: * $1 / * 7$ ) showed increased exposure, further studies are needed to confirm the hypothesis that SNPs in CYP3A5 do contribute to the interindividual variability in vincristine metabolism.

\section{Other cytotoxic drugs}

No SNPs analysed thus far appeared to affect the pharmacokinetic profile of cisplatin, melphalan, etoposide or doxorubicin in a way that can be considered clinically relevant.

Drugs in clinical development

To significantly improve the treatment of neuroblastoma, several studies were carried out to evaluate the potential of novel therapeutic alternatives. New approaches to circumvent the high resistance of neuroblastoma cells to chemotherapy 
could have a great impact on future treatment options. Seven new classes of drugs were identified that may contribute to that objective. Mechanisms of action, metabolic pathway and efficacy on neuroblastoma cells were assessed, with particular attention being paid to pharmacogenetic effects. Tables 4, 5, and 6 provide a summary of the findings from published pharmacogenetic studies.

\section{7-N-allylamino 17-demethoxygeldanamycin (17-AAG)}

Heat-shock protein 90 (Hsp90), an essential chaperone involved in the conformational maturation and stability of different proteins, including regulators of cellular proliferation and inhibitors of apoptosis, is constitutively overexpressed in tumour cell lines [124]. The great advantage of Hsp90 inhibitors should be the simultaneous depletion of multiple oncogenic client proteins [125]. Kang et al. [124] demonstrated the inhibition of SK-N-SH and LAN-1 neuroblastoma cell-line growth by 17-AAG, accompanied by reduced levels of Raf-1 and Akt protein kinases. On the other hand, Jayanthan et al. [125] showed that all neuroblastoma cell lines under evaluation (SK-N-MC, SK-N-SH, SK-N-BE2, IMR32, SH-Sy5y, LAN1, SHEP, IMR-5 and NUB-7) were sensitive to 17-AAG, with a half maximal inhibitory concentration $\left(\mathrm{IC}_{50}\right)$ value ranging from 0.5 to $5 \mu \mathrm{M}$ across different cell lines. In the same study, 17-AAG also sensitised neuroblastoma cells to various chemotherapeutic agents. 17AAG is metabolised by CYP3A4 and CYP3A5 to the active metabolite 17-AG and by nicotinamide adenine dinucleotide phosphate-oxidase (NADPH) dehydrogenase quinone 1 (NQO1) to the very active metabolite 17-AAGH2. The SNP $\mathrm{NQO} 1 * 2$, which seems to deplete enzyme activity, induces a 32-fold increase in 17-AAG resistance [96, 97], suggesting that such variation could have a relevant effect on the clinical response. Further studies are needed to characterise the role of NQO1 and other related polymorphisms in 17-AAG metabolism. In addition, it should be noted that polymorphisms affecting CYP450 are unlikely to influence the pharmacodynamics of 17-AAG because the metabolite has a similar activity to the parent compound.

\section{Aprepitant}

In addition to its role in the regulation of neurogenic inflammation, pain and depression, the activation of the neurokinin 1 (NK1) receptor by substance P induces mitogenesis and regulates active migration of tumour cells and angiogenetic processes. Aprepitant, a specific inhibitor of NK1, can inhibit both DNA synthesis and cell proliferation through the mitogen-activated protein kinase (MAPK) pathway [126]. In the study by Muñoz et al. [126], aprepitant showed a cytotoxic activity on all tested glioma, neuroblastoma, retinoblastoma, pancreatic carcinoma, larynx carcinoma, gastric carcinoma and colon carcinoma cell lines. Furthermore, after its administration, a great number of apoptotic cells were found in all tumour cell lines. Aprepitant is metabolised mainly by CYP3A4, with CYP1A2 and 2C19 as secondary metabolic routes. Thus far, as reported in Table 2, data on pharmacogenetic variation has not been reported.

\section{BMS-536924}

Through the IGF-1 receptor, insulin-like growth factor regulates many cellular survival mechanisms, such as cellular growth, differentiation, apoptosis, tumour angiogenesis and metastasis, and different tumour types have shown overexpression of this receptor [127]. All neuroblastoma cell lines tested in the study by Huang et al. [127] were sensitive to treatment with BMS-536924 $\left(\mathrm{IC}_{50}\right.$ range: 0.136-0.277 $\mu \mathrm{mol} / \mathrm{L}$ ), a specific inhibitor of IGF-1R, but the treatment seems to be successful only when the receptor is on the critical path of the pathogenesis and tumour progression. The same study demonstrated an interaction between BMS-536924 and gefitinib [epidermal growth factor receptor (EGFR) inhibitor] or BMS690514 (panHER inhibitor). Such evidence raises an important issue regarding the mechanisms of resistance by single agents, which involves the adaptation to an IGF-independent growth mechanism. No pharmacogenetic data have been published on this drug.

\section{Eflornithine (alpha-difluoromethylornithine)}

Polyamines, essential molecules for cellular activity, are undoubtedly involved in tumour cell growth [128]. If their synthesis is inhibited, cell growth is stopped or severely retarded. One of the hallmarks of neuroblastoma MYCN-amplified cell lines is the polyamine expansion [129]. Ornithine decarboxylase (ODC1) is a key enzyme in the biosynthetic pathway of polyamines, and ODC1 at high levels correlates with poor outcome in neuroblastoma. Eflornithine [d,l- $\alpha$-difluoromethylornithine (DFMO)] has been shown to induce cell-cycle arrest (G1) inhibiting ODC1 in neuroblastoma cell lines. The underlying cause is a polyamine depletion that arrests the cell cycle through the cyclin-dependent kinase inhibitor (p27kip1) pathway. Wallick et al. [128] demonstrated its inhibitory activity on neuroblastoma cell lines LAN-1 and NMB-7, with a neartotal cessation of cellular growth after 3 days. Whereas Koomoa et al. [130] confirmed the inhibition of LAN-1 proliferation, in another study by Rounbehler et al. [131], DFMO preferentially abolished the growth of MYCNamplified cell lines. DFMO also increased the effects of chemotherapy without additional toxicity [129]. It is important to point out that the polyamine depletion, besides cell-cycle arrest, also induces a mechanism of cell 
survival through the PI3K/Akt pathway that could explain a possible moderate efficacy of DFMO alone. Given that eflornithine is not metabolised, pharmacogenetic information pertinent to drug disposition is not available.

\section{Imatinib mesylate}

The 2-phenylaminopyrimidine imatinib is a specific inhibitor of Trk enzymes. It binds the Trk domain of Abl, c-kit (or CD117), and platelet-derived growth factor receptor (PDGF-R). C-Kit and PDGF-R were detected in neuroblastoma [132-134], and the cytokine receptor seems to be expressed mainly in the most aggressive forms of the tumour [135]. PDGF plays an important role in controlling growth, differentiation and survival of glial cells and immature neuroblasts, whereas c-Kit is essential for normal haematopoiesis, gametogenesis and melanogenesis [134]. In vitro studies by Vitali et al., Beppu et al., Rossler et al., and Palmberg et al. [132-135] demonstrated the ability of imatinib to inhibit neuroblastoma proliferation. Imatinib is metabolised by a large number of enzymes of the CYP450 family, with a major role played by CYP3A4 and CYP3A5. It is also a substrate of the ATP-binding cassette (ABC) transporters, P-glycoprotein (Pgp) and ABCG2. The most common polymorphisms associated with these routes only have a limited influence on imatinib pharmacokinetics and therefore do not seem to be the underlying cause of the high interindividual variability observed in clinical data $[98,136]$.

\section{Nutlin-3}

Murine double minute (MDM2) is a negative regulator of p53. It prevents p53 control on cell cycle and apoptosis, inhibiting transcriptional activation of the tumour suppressor. However, the effectiveness of an MDM2 inhibitor is evident only if p53 is functional. Given this prerequisite, it is important to emphasise that $<2 \%$ of neuroblastoma tumours exhibit mutations on the TP53 gene [137]. Nutlin-3 is a specific chiral inhibitor of MDM2, which induces G1 cellcycle arrest, apoptosis and neuronal differentiation in neuroblastoma cells [137-140], with an $\mathrm{IC}_{50}$ value of $3.25 \mu \mathrm{mol} / \mathrm{L}$ [141]. The 3a enantiomer shows a 200 -fold higher affinity for MDM2 than the enantiomer 3b [141]. Nutlin-3 is also a Pgp substrate, and both enantiomers increase the cytotoxic activity of anticancer agents that are substrates of Pgp (e.g., Vincristine) [140]. No pharmacogenetic information is available for this compound.

\section{Oncolytic virus}

Oncolytic viruses represent a new important therapeutic approach in cancer treatment [142-145]. They can circumvent chemotherapy-induced resistance mechanisms through a specific lysis of tumour cells. In addition, evidence exists of their efficacy and safety in clinical trials [146-148]. They basically act by inducing cell lysis, and genetic mutations applied to their genome restrict viral replication only to the tumour cells. An interesting feature of these viruses is the opportunity to incorporate an additional mechanism of action by arming the virus against specific targets (examples are listed below).

Neuroblastoma cells show evidence of cancer stem cells, as confirmed by the expression of various stem-cell markers such as CD34, CD133, and nestin. These cells can form tumorspheres extremely resistant to chemotherapy treatment and cause tumour relapse [146]. Given that neuroblastoma is also highly susceptible to herpes simplex virus (HSV)-mediated oncolysis [147, 149, 150], the use of HSV represents the best solution for a possible application in neuroblastoma treatment.

On the other hand, nestin, a protein expressed in nerve cells and involved in radial growth of the axon, is one of the possible options with which to arm an oncolytic virus. Thomas et al. [151] and Mahller et al. [146] demonstrated a correlation between nestin expression and MYCN amplification, although the same correlation was not shown in the study by Korja et al. [152]. In the former study, rQNestin34.5 oHSV abolished tumour formation for $>60$ days in mice affected by neuroblastoma [146].

Other possible options, besides the nestin-targeted vector, is the use of HSV armed with immunomodulatory molecules [B7-1, interleukin (IL)-12 and IL-18], armed against activated Rat sacroma (Ras)-signalling pathway, or with inhibitors of the matrix metalloproteinases (TIMP-3), as demonstrated respectively by Ino et al., Li et al. and Mahller et al. $[147,148,150]$. No pharmacogenetic data have been found for this type of intervention.

\section{Discussions and conclusion}

To date, limited improvement in survival rates has been achieved for high-risk patients with neuroblatoma. In this review, we have explored whether pharmacogenetic variation in pharmacokinetics could explain treatment failure. In addition, we have attempted to highlight some of the research gaps in the evaluation of novel molecules for neuroblastoma treatment. Numerous pharmacogenetic studies have been performed during the last 10 years, but most of them are basically related to drug disposition, rather than to pharmacodynamics. Based on the published literature, pharmacokinetic polymporphisms do not seem to be the cause of the low survival rate in neuroblastoma. None of the SNPs analysed thus far can explain the poor prognosis in high-risk patients following a variety of treatment options. The lack of correlation between response and pharmacogenetic factors may also reflect 
the context in which drugs are used (i.e. response is the result of a multimodal approach to neuroblastoma). Furthermore, it can be inferred from the low therapeutic failure in low- and intermediate-risk patients that the presence of pharmacokinetic polymorphisms in those groups does not alter treatment response rate. Assuming that systemic pharmacokinetics is independent of disease severity, it is conceivable that tumour factors associated with tissue kinetics (e.g. changes in Pgp expression) could lead to relevant differences in tumour exposure. Even though such differences at tissue level cannot be captured by the analysis of blood or plasma data, pharmacodynamic variants may ultimately underlie differences in response rates.

From the available data, only a few of the large number of polymorphisms have a clinically relevant effect on pharmacokinetics. Among these, SNPs UGT1A1*28 (already part of the label of CAMPTOSAR in the USA) and UGT1A1*6 were shown to affect the pharmacokinetic profile of irinotecan. Both polymorphisms cause an increase in the exposure to the active metabolite $\mathrm{SN}-38$ and consequently the risk for neutropenia. Moreover, it was shown that polymorphisms affecting the CYP3A5 can alter the pharmacokinetics of vincristine, given that this isozyme plays a key role in vincristine elimination. The same can be assumed from the investigation by Kelland et al. and Guo et al. on NQO1. This enzyme metabolises 17-AAG to the active metabolite 17$\mathrm{AAGH} 2$; and the polymorphic variant $\mathrm{NQO} 1 * 2$, which causes deletion of enzymatic activity, increases treatment resistance by 32 -fold.

From the examples above, it is clear that genetic variation in drug metabolism is not always clinically relevant per se. Its relevance depends on the enzyme affected, its impact on the metabolic capacity and especially on the contribution of the pathway to the overall clearance of a given drug. The same concept is applicable to the role of pharmacogenetics on active transporters and their implications for drug disposition. Taking these considerations into account, one needs to characterise a drug's overall pharmacokinetic profile to evaluate and demonstrate the potential consequences of genetic polymorphisms. Given that compensatory pathways are involved in the disposition of the majority of drugs suitable for clinical use, it can be anticipated that pharmacogenetic variation in absorption, distribution, metabolism, and excretion (ADME) will often have limited impact on the variability observed in pharmacodynamics and response. On the other hand, pharmacogenetic variation should not be overlooked if single pathways are known to determine drug disposition. This is one of the reasons so few drug labels yield useful pharmacogenetic information. In fact, numerous other intrinsic and extrinsic factors can influence pharmacokinetics, including variation in dosing regimen, treatment compliance, drug-drug interactions, demographic covariates, disease and organ function. For instance, in the specific case of neuroblastoma, most patients are aged between 0 and 4-5 years, and the large variability in exposure could exclusively be assigned to developmental growth (i.e. ontogeny) rather than genetic variation. Furthermore, other important elements such as organ function (i.e. disease severity) and drug-drug interactions are likely to have equal or higher impact than pharmacogenetic factors on drug disposition.

In brief, the scenario arising from this review confirms the need for an integrated approach to the evaluation of genetic variation in ADME processes. Inferences about the clinical implications of a polymorphism depend upon an integrated assessment of the exposure-response relationship. With regard to drugs under clinical investigation, our review has identified compounds with prominent pharmacological activity on neuroblastoma cells, irrespective of the level of resistance and MYCN amplification. Amongst them, oncolytic viruses have raised great interest due to the evidence of a cancer stem cell, which may underlie the high resistance to chemotherapy. Oncolytic treatment, circumventing the traditional mechanism of resistance, seems to be a valuable solution to improve treatment outcome. At this time, however, it is difficult to state whether such activity translates into clinical efficacy. Further studies are needed to confirm the clinical value of novel classes of drugs in neuroblastoma treatment. Moreover, effective drug combinations and dosing algorithms still need to be identified to ensure maximum effectiveness for most compounds.

Going back to the role of pharmacogenetics, this review shows the importance of the context in which a drug is used for the evaluation of polymorphisms. Many intrinsic and extrinsic factors influence pharmacokinetics, pharmacodynamics and overall response to treatment. Therefore, an isolated analysis of the role of pharmacogenetic factors on ADME processes would probably lead to biased results. All other relevant covariates should be considered in the statistical analysis of pharmacogenetic data. In this sense, many pharmacogenetic studies summarised in this review have not considered such an integrated approach or included details about the primary pharmacokinetic parameters.

In conclusion, pharmacogenetics is only one of many factors associated with pharmacokinetic variability. A model-based approach is required to address questions regarding the impact of polymorphism on clinical response and, as such, should become best practice in the analysis of pharmacogenetic data [153-157]. In a model-based approach, data analysis comprises the use of mathematical and statistical concepts that describe longitudinal data (i.e. a disease model), exposure-response relationships (i.e. a drug model) and clinical trial design features (i.e., an implementation model) in an intergrated manner. The main advantage of this approach is that all relevant covariates (such as age, 
weight, ethnicity, etc.) can be taken into account concurrently. Furthermore, between- and within-subject variability is assessed parametrically in terms of physiological parameters, such as clearance and volume of distribution, rather than relying on the observed variables (e.g. peak concentration, $\mathrm{C}_{\max }$ ), which are often prone to experimental artefacts. In this sense, modelling represents an effective strategy for translating the clinical implications of pharmacogenetic variation. Most importantly, it can support the selection and individualisation of dosing regimens, which may be more critical for efficacy than the effects of ADME polymorphism in high-risk patients with neuroblastoma.
Acknowledgements This contribution is part of the Task-force in Europe for Drug Development in the Young (TEDDY) Network of Excellence supported by the European Commission's Sixth Framework Program (Contract n. 0005216 LSHBCT-2005-005126).

Conflict of interest statement There are no arrangements of financial nature, or of any other kind, that could lead to conflict of interests with regard to this manuscript.

Open Access This article is distributed under the terms of the Creative Commons Attribution Noncommercial License which permits any noncommercial use, distribution, and reproduction in any medium, provided the original author(s) and source are credited.

\section{Appendix}

Table 1 Influence of pharmacogenetics on the pharmacokinetic profile of cytotoxic drugs

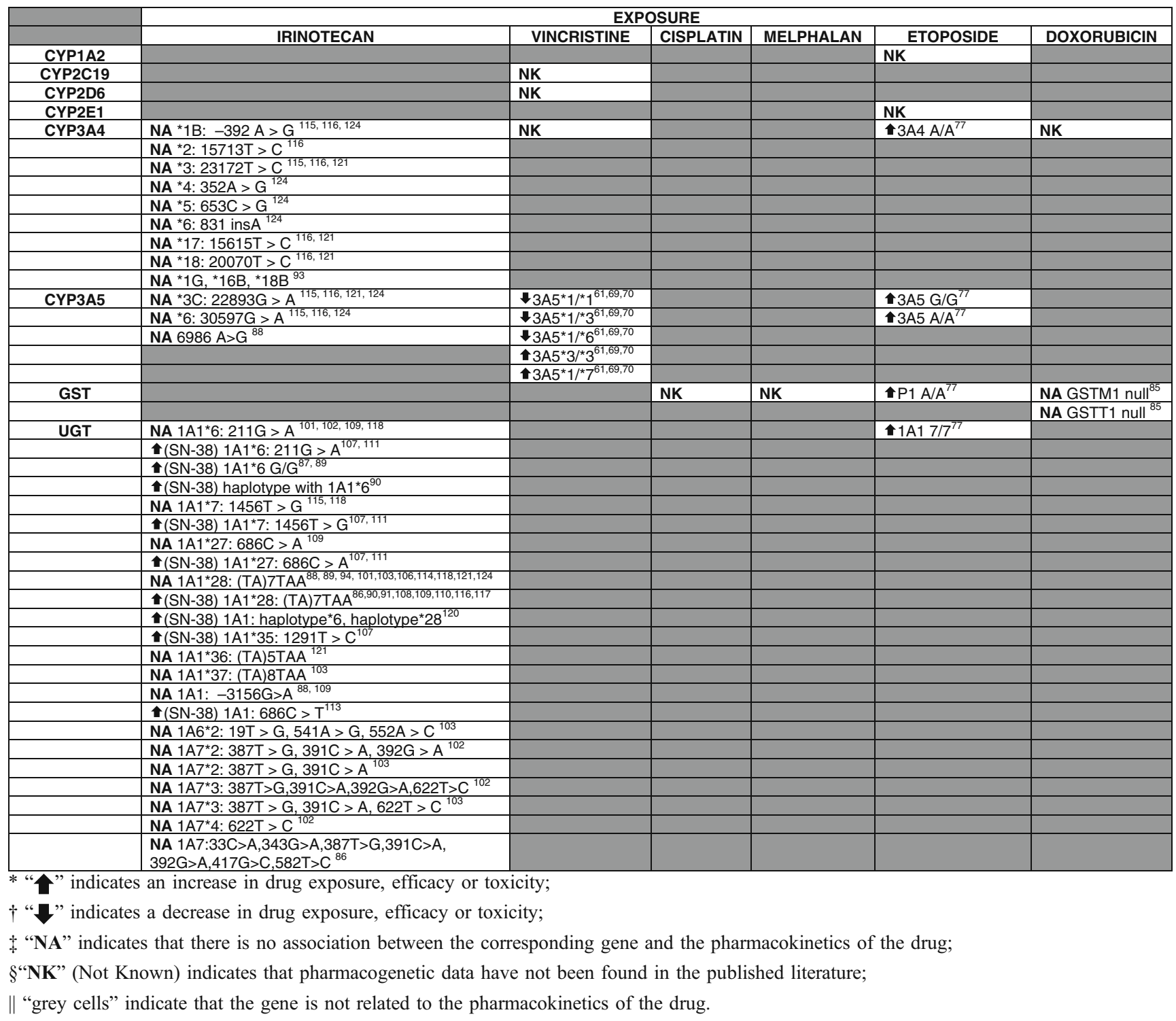


Table 1 (continued)

\begin{tabular}{|c|c|c|c|c|c|c|}
\hline & \multicolumn{6}{|c|}{ EXPOSURE } \\
\hline & IRINOTECAN & VINCRISTINE & CISPLATIN & MELPHALAN & ETOPOSIDE & DOXORUBICIN \\
\hline \multirow[t]{20}{*}{ UGT } & NA $1 A 7^{*} 2: 387 \mathrm{~T}>\mathrm{G}, 391 \mathrm{C}>\mathrm{A}^{107}$ & & & & & \\
\hline & NA $1 A 7^{\star} 2: 387 T>G, 391 C>A^{122}$ & & & & & \\
\hline & $(S N-38) 1 A 7^{*} 3: 387 T>G, 391 C>A, 622 T>C^{107}$ & & & & & \\
\hline & $(S N-38) 1 A 7^{*} 3: 387 T>G, 391 C>A, 622 T>C^{122}$ & & & & & \\
\hline & $(\mathrm{SN}-38) 1 \mathrm{~A}^{*} 4: 622 \mathrm{~T}>\mathrm{C}^{107}$ & & & & & \\
\hline & $(\mathrm{SN}-38) 1 \mathrm{~A}^{*} 4: 622 \mathrm{~T}>\mathrm{C}^{122}$ & & & & & \\
\hline & $(\mathrm{SN}-38) 1 \mathrm{~A} 7^{*} 5:(\mathrm{G} 115 \mathrm{~S})^{122}$ & & & & & \\
\hline & NA $1 A 7^{*} 6:(E 139 D)^{122}$ & & & & & \\
\hline & NA $1 A 7^{*} 7: 387 \mathrm{~T}>\mathrm{G}, 391 \mathrm{C}>\mathrm{A},(\mathrm{E} 139 \mathrm{D})^{122}$ & & & & & \\
\hline & $\begin{array}{l}\text { (SN-38) } 1 \mathrm{~A} 7^{*} 8: 387 \mathrm{~T}>\mathrm{G} \\
391 \mathrm{C}>\mathrm{A},(\mathrm{E} 139 \mathrm{D}), 622 \mathrm{~T}>\mathrm{C}^{122}\end{array}$ & & & & & \\
\hline & $(\mathrm{SN}-38) 1 \mathrm{~A} 7^{*} 9:(\mathrm{G} 115 \mathrm{~S}), 387 \mathrm{~T}>\mathrm{G}, 391 \mathrm{C}>\mathrm{A}^{122}$ & & & & & \\
\hline & NA $1 A^{*} 9^{*} 2^{86}$ & & & & & \\
\hline & NA $1 A 9 * 3: 98 T>C^{117}$ & & & & & \\
\hline & NA $1 A 9 * 3: 98 T>C^{86}$ & & & & & \\
\hline & NA $1 A 9^{*} 5: 766 G>A^{117}$ & & & & & \\
\hline & NA 1 A $9-118(\mathrm{dT}) 9 / 9^{103}$ & & & & & \\
\hline & $\begin{array}{l}\text { NA Haplotype: UGT1A1*1, UGT1A6*1, } \\
\text { UGT1A } 7^{*} 1, \text { UGT1A9-118 (dT) } 10 / 10^{103}\end{array}$ & & & & & \\
\hline & NA $1 A 9 * 2: 8 G>A^{122}$ & & & & & \\
\hline & $(\mathrm{SN}-38) 1 \mathrm{~A}^{*} 3: 98 \mathrm{~T}>\mathrm{C}^{122}$ & & & & & \\
\hline & $(S N-38) 1 A 9^{*} 5: 766 G>A^{112}$ & & & & & \\
\hline \multirow[t]{7}{*}{ CBR1 } & & & & & & NA c. $219 \mathrm{G}>\mathrm{C}^{79}$ \\
\hline & & & & & & $c .627 \mathrm{C} / \mathrm{C}^{79}$ \\
\hline & & & & & & $+967 \mathrm{G} / \mathrm{G}^{79}$ \\
\hline & & & & & & $\begin{array}{l}\text { diplotype } \\
\text { (c. } 627 \mathrm{C}+967 \mathrm{G})^{79}\end{array}$ \\
\hline & & & & & & $1096 \mathrm{G} / \mathrm{G}^{80}$ \\
\hline & & & & & & $-V 881^{82}$ \\
\hline & & & & & & NA P131S ${ }^{82}$ \\
\hline CBR3 & & & & & & NA $^{79}$ \\
\hline \multirow[t]{2}{*}{ CES1 } & NA $1440 A>T^{115}$ & & & & & \\
\hline & NA 1525 A $>C^{115}$ & & & & & \\
\hline \multirow[t]{10}{*}{ CES2 } & NA $1647 C>T^{115}$ & & & & & \\
\hline & NA *1: $803 C>G, 8721 G>A, 9938 G>A, 9943 C>A^{104}$ & & & & & \\
\hline & NA $* 2: 8721 G>A$ A 04 & & & & & \\
\hline & $\begin{array}{l}\text { NA *3: } 8721 G>A, 9607 C>T, 9624 A>G \\
9938 G>A, 9943 C>A^{104}\end{array}$ & & & & & \\
\hline & NA *4: $8721 G>A, 9938 G>A, 9943 C>A^{104}$ & & & & & \\
\hline & NA*7: 4595T > C ${ }^{104}$ & & & & & \\
\hline & NA *8: $7339 G>A^{104}$ & & & & & \\
\hline & NA *10: $1216 \mathrm{~T}>\mathrm{C}, 9938 \mathrm{G}>\mathrm{A}, 9943 \mathrm{C}>\mathrm{A}^{104}$ & & & & & \\
\hline & NA Haplotype 50-UTR-363, Intron1 + $1361^{123}$ & & & & & \\
\hline & $\begin{array}{l}\text { NA Haplotype 50-UTR-363, Intron } 1+947 \text {, } \\
\text { Intron } 1+1361, \text { Intron } 1+1643^{123}\end{array}$ & & & & & \\
\hline
\end{tabular}


Table 1 (continued)

\begin{tabular}{|c|c|c|c|c|c|c|}
\hline & \multicolumn{6}{|c|}{ EXPOSURE } \\
\hline & IRINOTECAN & VINCRISTINE & CISPLATIN & MELPHALAN & ETOPOSIDE & DOXORUBICIN \\
\hline \multirow[t]{2}{*}{ VDR } & & & & & - intron $8 \mathrm{AA} / \mathrm{AG}^{77}$ & \\
\hline & & & & & fok $1 \mathrm{TT}^{77}$ & \\
\hline \multirow[t]{6}{*}{ MDR1 } & & NA C3435T ${ }^{62}$ & NK & & NK G571A 72 & NA G571A 72 \\
\hline & & NA G2677T 62 & & & $3435 \mathrm{C} / \mathrm{C}^{77}$ & NK G1199A ${ }^{83}$ \\
\hline & & NK G1199A 71,83 & & & NK $3435 \mathrm{C} / \mathrm{C}^{78}$ & NA G1199A ${ }^{71}$ \\
\hline & & NK G571A 72 & & & $2677 \mathrm{G} / \mathrm{G}^{77}$ & NK G1199T ${ }^{83}$ \\
\hline & & NK G1199T ${ }^{83}$ & & & NA G2677T ${ }^{78}$ & \\
\hline & & & & & $\begin{array}{l}\text { NK Haplotype } \\
2677 G-3435 C^{78}\end{array}$ & \\
\hline MRP1 & & & NK & & & $\begin{array}{l}\text { NK Gly671Val } \\
\text { G/T, T/T } 81\end{array}$ \\
\hline MRP2 & & & NK & & & $\begin{array}{l}\text { NK haplotype } \\
\text { Val1188Glu- } \\
\text { Cys1515Tyr } \\
{ }^{81} \\
\end{array}$ \\
\hline \multirow[t]{6}{*}{ ABCB1(MDR1) } & $\begin{array}{l}\text { (SN-38) Haplotype: } 1236 \mathrm{C}>\mathrm{T} \text {, } \\
2677 \mathrm{G}>\mathrm{T} \text {, and } 3435 \mathrm{C}>\mathrm{T}^{119}\end{array}$ & NA $893-$ Ser $^{63}$ & & & & \\
\hline & (SN-38) $1236 \mathrm{C}>\mathrm{T}^{115}$ & NA 893-Thr ${ }^{63}$ & & & & \\
\hline & NA $1236 \mathrm{C}>\mathrm{T}^{92,116,124}$ & & & & & \\
\hline & NA $2677 \mathrm{G}>\mathrm{T} / \mathrm{A}^{92,115,116,124}$ & & & & & \\
\hline & NA $3435 C>T^{88,92,115,116,121,124}$ & & & & & \\
\hline & (SN-38) diplotype $2677 \mathrm{G}-3435 \mathrm{C}^{92}$ & & & & & \\
\hline \multirow[t]{3}{*}{ ABCC1(MRP1) } & NA $462 C>T^{115}$ & & & & & \\
\hline & NA $14008 G>A^{115}$ & & & & & \\
\hline & NA $34215 C>G^{115}$ & & & & & \\
\hline \multirow[t]{6}{*}{$A B C C 2$} & NA $-24 T>C^{80,124}$ & & & & & \\
\hline & $3972 T>C^{86}$ & & & & & \\
\hline & NA $33449 T>C^{115}$ & & & & & \\
\hline & NA $156231 A>G^{124}$ & & & & & \\
\hline & *2 haplotype ${ }^{91}$ & & & & & \\
\hline & NA $1249 G>A, 3972 C>T^{92}$ & & & & & \\
\hline \multirow[t]{10}{*}{ ABCG2 } & $-19572-19576^{86,124}$ & & & & & \\
\hline & NA $-19202 G>C^{124}$ & & & & & \\
\hline & NA $-18845 T>\mathrm{C}^{124}$ & & & & & \\
\hline & NA -18604 delA ${ }^{124}$ & & & & & \\
\hline & NA $34 G>A^{80,124}$ & & & & & \\
\hline & NA $376 C>T^{124}$ & & & & & \\
\hline & NA $421 C>A^{89,92,105,124}$ & & & & & \\
\hline & $421 C>A^{86}$ & & & & & \\
\hline & NA $623 T>C^{115}$ & & & & & \\
\hline & NA $1444 A>G, 1445 G>C^{124}$ & & & & & \\
\hline ATP7A & & & NK & & & \\
\hline ATP7B & & & NK & & & \\
\hline CTR1 & & & NK & & & \\
\hline LAT1/LAT2 & & & & NA $^{74,75}$ & & \\
\hline hOCT2 & & & NA $^{64}$ & & & \\
\hline \multirow[t]{2}{*}{ SLC22A16 } & & & & & & c. $146 \mathrm{G} / \mathrm{G}^{84}$ \\
\hline & & & & & & NA c. $755 T>C^{84}$ \\
\hline CyclinD1/D2/D3 & & & NK & & & \\
\hline
\end{tabular}


Table 2 Influence of pharmacogenetics on the efficacy of cytotoxic drugs

\begin{tabular}{|c|c|c|c|c|c|c|}
\hline & \multicolumn{6}{|c|}{ EFFICACY } \\
\hline & IRINOTECAN & VINCRISTINE & CISPLATIN & MELPHALAN & ETOPOSIDE & DOXORUBICIN \\
\hline CYP1A2 & & & & & NK & \\
\hline CYP2C19 & & NK & & & & \\
\hline CYP2D6 & & NK & & & & \\
\hline CYP2E1 & & & & & NK & \\
\hline \multirow[t]{9}{*}{ CYP3A4 } & NA *1B: $-392 A>G^{115,116,124}$ & NK & & & NK & NK \\
\hline & NA ${ }^{*} 2: 15713 \mathrm{~T}>\mathrm{C}^{116}$ & & & & & \\
\hline & NA *3: $23172 T>C^{115,116,121}$ & & & & & \\
\hline & NA *4: $352 A>G^{124}$ & & & & & \\
\hline & $N^{*}{ }^{\star} 5: 653 C>G^{124}$ & & & & & \\
\hline & NA $^{*} 6: 831$ insA $^{124}$ & & & & & \\
\hline & NA *17: $15615 \mathrm{~T}>\mathrm{C}^{116,121}$ & & & & & \\
\hline & NA *18: $20070 T>C^{116,121}$ & & & & & \\
\hline & NA $* 1 \mathrm{G},{ }^{*} 16 \mathrm{~B},{ }^{*} 18 \mathrm{~B}^{93}$ & & & & & \\
\hline \multirow[t]{5}{*}{ CYP3A5 } & NA *3C: $22893 G>A^{115,116,121,124}$ & NK $3 A 5^{*} 1 /{ }^{*} 1^{61,69,70}$ & & & NK & \\
\hline & NA *6: $30597 \mathrm{G}>\mathrm{A}^{115,116,124}$ & NK $3 A 5^{\star} 1 /{ }^{*} 3^{61,69,70}$ & & & & \\
\hline & NA $6986 \mathrm{~A}>\mathrm{G}^{88}$ & NK $3 A 5^{*} 1 /{ }^{*} 6^{61,69,70}$ & & & & \\
\hline & & NK $3 A 5^{\star} 3 /{ }^{*} 3^{61,69,70}$ & & & & \\
\hline & & NK $3 A 5^{\star} 1 /{ }^{*} 7^{61,69,70}$ & & & & \\
\hline \multirow[t]{2}{*}{ GST } & & & NK & NK & NK & NA GSTM1 null $^{85}$ \\
\hline & & & & & & NA GSTT1 null ${ }^{85}$ \\
\hline \multirow[t]{23}{*}{ UGT } & NA $1 A 1^{*} 6: 211 G>A^{101,102,109,118}$ & & & & NK & \\
\hline & NA $1 A 1^{*} 6: 211 G>A^{107,111}$ & & & & & \\
\hline & NK $1 \mathrm{~A} 1^{*} 6^{87,89,90}$ & & & & & \\
\hline & NA $1 \mathrm{~A} 11^{\star} 7: 1456 \mathrm{~T}>\mathrm{G}^{107,111,115,118}$ & & & & & \\
\hline & NA $1 \mathrm{~A} 11^{\star} 27: 686 \mathrm{C}>\mathrm{A}^{107,109,111}$ & & & & & \\
\hline & NA 1A1*28: (TA)7TAA $88,89,94,101,103,106,114,118,121,124$ & & & & & \\
\hline & NA 1A1*28: (TA)7TAA $86,90,91,108,109,110,116,117$ & & & & & \\
\hline & NA $1 \mathrm{~A} 1 * 35: 1291 \mathrm{~T}>\mathrm{C}^{107}$ & & & & & \\
\hline & NA 1A1*36: (TA)5TAA ${ }^{121}$ & & & & & \\
\hline & NA $1 \mathrm{~A} 11^{\star} 37:(\mathrm{TA}) 8 \mathrm{TAA}^{103}$ & & & & & \\
\hline & NA 1A1: $-3156 \mathrm{G}>\mathrm{A}^{88,109}$ & & & & & \\
\hline & NA $1 \mathrm{~A} 1: 686 \mathrm{C}>\mathrm{T}^{113}$ & & & & & \\
\hline & NA $1 A 6 * 2: 19 T>G, 541 A>G, 552 A>C^{103}$ & & & & & \\
\hline & NA $1 A 7^{\star} 2: 387 T>G, 391 C>A, 392 G>A^{102}$ & & & & & \\
\hline & $1 A 7^{*} 2: 387 T>G, 391 C>A^{103}$ & & & & & \\
\hline & NA $1 A 7^{\star} 3: 387 T>G, 391 C>A, 392 G>A, 622 T>C^{102}$ & & & & & \\
\hline & $1 A 7^{\star} 3: 387 T>G, 391 C>A, 622 T>C^{103}$ & & & & & \\
\hline & NA $1 \mathrm{~A} 77^{*} 4: 622 \mathrm{~T}>\mathrm{C}^{102}$ & & & & & \\
\hline & $\begin{array}{l}\text { NA } 1 A 7: 33 C>A, 343 G>A, 387 T>G, 391 C>A \\
392 G>A, 417 G>C, 582 T>C{ }^{86}\end{array}$ & & & & & \\
\hline & NA $1 A 7^{\star} 2: 387 T>G, 391 C>A^{107}$ & & & & & \\
\hline & NA $1 A 7^{*} 2: 387 T>G, 391 C>A^{122}$ & & & & & \\
\hline & NA $1 A 7 * 3: 387 T>G, 391 C>A, 622 T>C^{107}$ & & & & & \\
\hline & NA $1 A 7 * 3: 387 T>G, 391 C>A, 622 T>C^{122}$ & & & & & \\
\hline
\end{tabular}

* " indicates an increase in drug exposure, efficacy or toxicity;

$\dagger$ " $"$ " indicates a decrease in drug exposure, efficacy or toxicity;

\$ "NA" indicates that there is no association between the corresponding gene and the pharmacokinetics of the drug;

$\S$ "NK" (Not Known) indicates that pharmacogenetic data have not been found in the published literature;

|| "grey cells" indicate that the gene is not related to the pharmacokinetics of the drug. 
Table 2 (continued)

\begin{tabular}{|c|c|c|c|c|c|c|}
\hline & \multicolumn{6}{|c|}{ EFFICACY } \\
\hline & IRINOTECAN & VINCRISTINE & CISPLATIN & MELPHALAN & ETOPOSIDE & DOXORUBICIN \\
\hline \multirow[t]{16}{*}{ UGT } & NA $1 A 7 * 4: 622 T>C^{107}$ & & & & & \\
\hline & NA $1 A 7 * 4: 622 T>C^{122}$ & & & & & \\
\hline & NA $1 A 7 * 5:(G 115 S)^{122}$ & & & & & \\
\hline & NA $1 A 7^{*} 6:(E 139 D)^{122}$ & & & & & \\
\hline & NA $1 \mathrm{~A} 77^{\star} 7: 387 \mathrm{~T}>\mathrm{G}, 391 \mathrm{C}>\mathrm{A},(\mathrm{E} 139 \mathrm{D})^{122}$ & & & & & \\
\hline & NA $1 A 7^{\star} 8:$ 387T $>G, 391 C>A,(E 139 D), 622 T>C^{122}$ & & & & & \\
\hline & NA $1 A 7^{\star} 9:(G 115 S), 387 T>G, 391 C>A^{122}$ & & & & & \\
\hline & NA $1 A 9 * 2^{86}$ & & & & & \\
\hline & NA $1 A 9^{*} 3: 98 T>C^{117}$ & & & & & \\
\hline & NA $1 A 9^{\star} 3: 98 T>C^{86}$ & & & & & \\
\hline & NA $1 A^{*} 5: 766 G>A^{117}$ & & & & & \\
\hline & $1 \mathrm{~A} 9-118(\mathrm{dT}) 9 / 9^{103}$ & & & & & \\
\hline & $\begin{array}{l}\text { Haplotype: UGT1A1*1,UGT1A6*1, } \\
\text { UGT1A7*1,UGT1A9-118(dT) } 10 / 10\end{array}$ & & & & & \\
\hline & NA $1 A^{*} 2: 8 G>A^{122}$ & & & & & \\
\hline & NA $1 A 9 * 3: 98 T>C^{122}$ & & & & & \\
\hline & NA $1 A^{\star} 5: 766 G>A^{112}$ & & & & & \\
\hline \multirow[t]{7}{*}{ CBR1 } & & & & & & NA c. $219 \mathrm{G}>\mathrm{C}^{79}$ \\
\hline & & & & & & NK c. $627 \mathrm{C} / \mathrm{C}^{79}$ \\
\hline & & & & & & NK $967 \mathrm{G} / \mathrm{G}^{79}$ \\
\hline & & & & & & 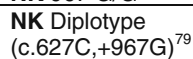 \\
\hline & & & & & & NK $1096 \mathrm{G} / \mathrm{G}^{80}$ \\
\hline & & & & & & NK V881 ${ }^{82}$ \\
\hline & & & & & & NA P131S ${ }^{82}$ \\
\hline CBR3 & & & & & & NA $^{79}$ \\
\hline \multirow[t]{2}{*}{ CES1 } & NA $1440 A>T^{115}$ & & & & & \\
\hline & NA $1525 \mathrm{~A}>\mathrm{C}^{115}$ & & & & & \\
\hline \multirow[t]{10}{*}{ CES2 } & NA $1647 \mathrm{C}>\mathrm{T}^{115}$ & & & & & \\
\hline & $N A * 1: 803 C>G, 8721 G>A, 9938 G>A, 9943 C>A^{104}$ & & & & & \\
\hline & NA *2: $8721 G>A^{104}$ & & & & & \\
\hline & $\begin{array}{l}\text { NA *3: } 8721 G>A, 9607 C>T, 9624 A>G \\
9938 G>A, 9943 C>A \\
104\end{array}$ & & & & & \\
\hline & NA * $4: 8721 G>A, 9938 G>A, 9943 C>A^{104}$ & & & & & \\
\hline & NA ${ }^{*} 7: 4595 T>C^{104}$ & & & & & \\
\hline & NA *8: $7339 G>A^{104}$ & & & & & \\
\hline & NA *10: $1216 T>C, 9938 G>A, 9943 C>A^{104}$ & & & & & \\
\hline & NA Haplotype 50-UTR-363, Intron $1+1361^{123}$ & & & & & \\
\hline & $\begin{array}{l}\text { NA Haplotype 50-UTR363, Intron1+947, } \\
\text { Intron1+1361,Intron } 1+1643^{123}\end{array}$ & & & & & \\
\hline VDR & & & & & NK & \\
\hline \multirow[t]{3}{*}{ MDR1 } & & NA C3435T ${ }^{62}$ & NA $^{66}$ & & $G 571 A^{72}$ & NA G571A 72 \\
\hline & & NA G2677T 62 & & & NK $3435 \mathrm{C} / \mathrm{C}^{77}$ & G1199A 83 \\
\hline & & G1199A 71,83 & & & $3435 \mathrm{C} / \mathrm{C}^{78}$ & NA G1199A \\
\hline
\end{tabular}


Table 2 (continued)

\begin{tabular}{|c|c|c|c|c|c|c|}
\hline & & & & & $2677 \mathrm{G}-3435 \mathrm{C}^{18}$ & \\
\hline MRP1 & & & $\mathbf{N A}^{66}$ & & & $\begin{array}{l}\text { NK Gly671Val } \\
\text { G/T, T/T }{ }^{81}\end{array}$ \\
\hline MRP2 & & & $\mathbf{N A}^{66}$ & & & $\begin{array}{l}\text { NK Haplotype } \\
\text { Val1188GluCys } \\
\text { 1515Tyr }\end{array}$ \\
\hline \multirow[t]{4}{*}{ ABCB1(MDR1) } & NA Haplotype: $1236 \mathrm{C}>\mathrm{T}, 2677 \mathrm{G}>\mathrm{T}$, and $3435 \mathrm{C}>\mathrm{T}^{119}$ & NA $893-$ Ser $^{63}$ & & & & \\
\hline & NA $1236 \mathrm{C}>T^{92,115,116,124}$ & NA $893-\mathrm{Thr}^{63}$ & & & & \\
\hline & NA $2677 \mathrm{G}>\mathrm{T} / \mathrm{A}^{92,115,116,124}$ & & & & & \\
\hline & NA $3435 C>T^{88,92,115,116,121,124}$ & & & & & \\
\hline \multirow[t]{3}{*}{ ABCC1(MRP1) } & NA $462 C>T^{115}$ & & & & & \\
\hline & NA $14008 \mathrm{G}>\mathrm{A}^{115}$ & & & & & \\
\hline & NA $34215 C>G^{115}$ & & & & & \\
\hline \multirow[t]{6}{*}{ ABCC2 } & NA $-24 T>C^{92,124}$ & & & & & \\
\hline & NA $3972 T>C^{86}$ & & & & & \\
\hline & NA $33449 T>C^{115}$ & & & & & \\
\hline & NA $156231 A>G^{124}$ & & & & & \\
\hline & $\mathbf{N A} * 2^{92}$ & & & & & \\
\hline & NA $1249 \mathrm{G}>\mathrm{A}, 3972 \mathrm{C}>\mathrm{T}^{92}$ & & & & & \\
\hline \multirow[t]{9}{*}{ ABCG2 } & NA $-19572-19576^{86,124}$ & & & & & \\
\hline & $\mathbf{N A}-19202 \mathrm{G}>\mathrm{C}^{124}$ & & & & & \\
\hline & NA $-18845 \mathrm{~T}>\mathrm{C}^{124}$ & & & & & \\
\hline & NA -18604 delA 124 & & & & & \\
\hline & NA $34 G>A^{92,124}$ & & & & & \\
\hline & NA 376 C > T ${ }^{124}$ & & & & & \\
\hline & NA $421 C>A^{86,89,92,105,124}$ & & & & & \\
\hline & NA $623 T>C^{115}$ & & & & & \\
\hline & NA $1444 A>G, 1445 G>C^{124}$ & & & & & \\
\hline ATP7A & & & NK & & & \\
\hline ATP7B & & & NK & & & \\
\hline CTR1 & & & NK & & & \\
\hline LAT1/LAT2 & & & & $\mathbf{N A}^{74,75}$ & & \\
\hline hOCT2 & & & NA $^{64}$ & & & \\
\hline SLC22A16 & & & & & & NK c. $146 \mathrm{G} / \mathrm{G}^{84}$ \\
\hline & & & & & & NA c. $755 T>C^{84}$ \\
\hline CyclinD1/D2/D3 & & & NA $^{61}$ & & & \\
\hline
\end{tabular}


Table 3 Influence of pharmacogenetics on the toxicity of cytotoxic drugs

\begin{tabular}{|c|c|c|c|c|c|c|}
\hline & \multicolumn{6}{|c|}{ TOXICITY } \\
\hline & IRINOTECAN & VINCRISTINE & CISPLATIN & MELPHALAN & ETOPOSIDE & DOXORUBICIN \\
\hline CYP1A2 & & & & & NK & \\
\hline CYP2C19 & & NK & & & & \\
\hline CYP2D6 & & NK & & & & \\
\hline CYP2E1 & & & & & NK & \\
\hline \multirow[t]{9}{*}{ CYP3A4 } & NA *1B: $-392 A>G^{115,116,124}$ & NK & & & NK & NK \\
\hline & NA $* 2: 15713 T>C^{116}$ & & & & & \\
\hline & NA $* 3: 23172 T>C^{115,116,121}$ & & & & & \\
\hline & NA * $4: 352 A>G^{124}$ & & & & & \\
\hline & NA *5: $653 C>G^{124}$ & & & & & \\
\hline & NA $* 6: 831$ insA ${ }^{124}$ & & & & & \\
\hline & NA *17: $15615 T>C^{116,121}$ & & & & & \\
\hline & NA *18: $20070 T>C^{116,121}$ & & & & & \\
\hline & NA ${ }^{*} 1 G,{ }^{*} 16 B,{ }^{*} 18 B^{93}$ & & & & & \\
\hline \multirow[t]{5}{*}{ CYP3A5 } & NA *3C: $22893 G>A^{115,116,121,124}$ & NK $3 A 5^{*} 1 /{ }^{*} 1^{61,69,70}$ & & & NK & \\
\hline & NA $* 6: 30597 G>A^{115,116,124}$ & NK $3 A 5^{*} 1 /{ }^{*} 3^{61,69,70}$ & & & & \\
\hline & NA $6986 A>G^{88}$ & NK $3 A 5^{*} 1 /{ }^{*} 6^{61,69,70}$ & & & & \\
\hline & & NK $3 A 5^{*} 3 /{ }^{*} 3^{61,69,70}$ & & & & \\
\hline & & NK $3 A 5^{\star} 1 /{ }^{\star} 7^{61,69,70}$ & & & & \\
\hline \multirow[t]{6}{*}{ GST } & & & NA M1,T1,Z1 ${ }^{65}$ & NK & NK & NA GSTM1 null ${ }^{85}$ \\
\hline & & & $\mathrm{M}^{*} \mathrm{~B}^{65}$ & & & NA GSTT1 null ${ }^{85}$ \\
\hline & & & $P 1 G / G^{65}$ & & & \\
\hline & & & P $1 \mathrm{~A} / \mathrm{G}, \mathrm{A} / \mathrm{A}^{65}$ & & & \\
\hline & & & $\begin{array}{l}\text { P1 105Val } \\
/ 105 \mathrm{Val}^{73}\end{array}$ & & & \\
\hline & & & $\begin{array}{l}\text { P P1105Ile } \\
/ 105 \| \mathrm{e}^{73}\end{array}$ & & & \\
\hline \multirow[t]{17}{*}{ UGT } & NA $1 A 1^{*} 6: 211 G>A^{101,102,109,118}$ & & & & NK & \\
\hline & NA $1 A 1^{*} 6: 211 G>A^{107,111}$ & & & & & \\
\hline & $1 \mathrm{~A} 1^{*} 6 \mathrm{G} / \mathrm{G}^{87,89}$ & & & & & \\
\hline & diplotype with $1 \mathrm{~A} 1 * 6^{90}$ & & & & & \\
\hline & NA $1 A 1^{*} 7: 1456 T>G^{107,111,115,118}$ & & & & & \\
\hline & NA $1 A 1^{*} 27: 686 C>A^{107,109,111}$ & & & & & \\
\hline & $\begin{array}{l}\text { NA 1A1*28: (TA)7TAA } \\
\text { N8,89,90,91,94,103,106,108,110,117,121,124 }\end{array}$ & & & & & \\
\hline & 1A1*28: $(\mathrm{TA}) 7 \mathrm{TAA}^{101}$ & & & & & \\
\hline & 1A1*28: (TA)7TAA ${ }^{86,109,116,118}$ & & & & & \\
\hline & 1A1*28: (TA)7TAA ${ }^{114}$ & & & & & \\
\hline & NA 1A1*35: 1291T > C ${ }^{107}$ & & & & & \\
\hline & NA 1A1*36: (TA)5TAA ${ }^{121}$ & & & & & \\
\hline & NA 1A1*37: $(\mathrm{TA}) 8 \mathrm{TAA}^{103}$ & & & & & \\
\hline & 1A1: $-3156 \mathrm{~A} / \mathrm{A}^{88,109}$ & & & & & \\
\hline & NA $1 \mathrm{~A} 1: 686 \mathrm{C}>\mathrm{T}^{113}$ & & & & & \\
\hline & NA $1 A 6^{*} 2: 19 T>G, 541 A>G, 552 A>C^{103}$ & & & & & \\
\hline & NA $1 A 7^{*} 2: 387 T>G, 391 C>A, 392 G>A^{102}$ & & & & & \\
\hline \multicolumn{7}{|c|}{ " indicates an increase in drug exposure, efficacy or toxicity; } \\
\hline \multicolumn{7}{|c|}{ " indicates a decrease in drug exposure, efficacy or toxicity; } \\
\hline \multirow{2}{*}{\multicolumn{7}{|c|}{ "NA" indicates that there is no association between the corresponding gene and the pharmacokinetics of the drug; }} \\
\hline \multicolumn{3}{|c|}{ NK" (Not Known) indicates that pharmacogenetic data have not been found in the published literature; } & & & & \\
\hline
\end{tabular}


Table 3 (continued)

\begin{tabular}{|c|c|c|c|c|c|c|}
\hline & \multicolumn{6}{|c|}{ TOXICITY } \\
\hline & IRINOTECAN & VINCRISTINE & CISPLATIN & MELPHALAN & ETOPOSIDE & DOXORUBICIN \\
\hline \multirow[t]{25}{*}{ UGT } & $1 A 7^{*} 2: 387 T>G, 391 C>A^{103}$ & & & & & \\
\hline & $\begin{array}{l}\text { NA } 1 A 7^{\star} 3: \\
387 T>G, 391 C>A, 392 G>A, 622 T>C^{102}\end{array}$ & & & & & \\
\hline & $1 \mathrm{~A} 7^{*} 3: 387 \mathrm{~T}>\mathrm{G}, 391 \mathrm{C}>\mathrm{A}, 622 \mathrm{~T}>\mathrm{C}^{103}$ & & & & & \\
\hline & NA $1 A 7^{*} 4: 622 T>C^{102}$ & & & & & \\
\hline & $\begin{array}{l}\text { NA } 1 A 7: 33 C>A, 343 G>A, 387 T>G \text {, } \\
391 C>A, 392 G>A, 417 G>C, 582 T>C\end{array}$ & & & & & \\
\hline & NA $1 A 7^{*} 2: 387 T>G, 391 C>A^{107}$ & & & & & \\
\hline & NA $1 A 7^{*} 2: 387 T>G, 391 C>A^{122}$ & & & & & \\
\hline & NA $1 A 7 * 3: 387 T>G, 391 C>A, 622 T>C^{107}$ & & & & & \\
\hline & NA $1 A 7 * 3: 387 T>G, 391 C>A, 622 T>C^{122}$ & & & & & \\
\hline & NA $1 A 7 * 4: 622 T>C^{107}$ & & & & & \\
\hline & NA $1 A 7 * 4: 622 T>C^{122}$ & & & & & \\
\hline & NA $1 A 7 * 5:(G 115 S)^{122}$ & & & & & \\
\hline & NA $1 A 7^{*} 6:(E 139 D)^{122}$ & & & & & \\
\hline & NA $1 A 7^{*} 7: 387 T>G, 391 C>A,(E 139 D)^{122}$ & & & & & \\
\hline & NA $1 A 7 * 8: 387 T>G, 391 C>A,(E 139 D), 622 T>C^{122}$ & & & & & \\
\hline & NA $1 A 7^{*} 9:(G 115 S), 387 T>G, 391 C>A^{122}$ & & & & & \\
\hline & NA $1 A 9^{*} 2^{86}$ & & & & & \\
\hline & NA $1 \mathrm{~A} 9 * 3: 98 \mathrm{~T}>\mathrm{C}^{117}$ & & & & & \\
\hline & NA $1 A 9^{\star} 3: 98 T>C^{86}$ & & & & & \\
\hline & NA $1 A 9^{*} 5: 766 G>A^{117}$ & & & & & \\
\hline & $1 \mathrm{~A} 9-118(\mathrm{dT}) 9 / 9^{103}$ & & & & & \\
\hline & $\begin{array}{l}\text { NA Haplotype: UGT1A1*1,UGT1A6*1, } \\
\text { UGT1A7*1,UGT1A9-118(dT) } 10 / 10^{103}\end{array}$ & & & & & \\
\hline & NA $1 A 9^{*} 2: 8 G>A^{122}$ & & & & & \\
\hline & NA $1 A 9 * 3: 98 T>C^{122}$ & & & & & \\
\hline & NA $1 A 9 * 5: 766 G>A^{112}$ & & & & & \\
\hline \multirow[t]{7}{*}{ CBR1 } & & & & & & NA c. $219 \mathrm{G}>\mathrm{C}^{79}$ \\
\hline & & & & & & NK c. $627 \mathrm{C} / \mathrm{C}^{79}$ \\
\hline & & & & & & NK $967 \mathrm{G} / \mathrm{G}^{79}$ \\
\hline & & & & & & $\begin{array}{l}\text { NK Diplotype } \\
{\text { (c. } 627,+967 G)^{79}}^{9}\end{array}$ \\
\hline & & & & & & NK $1096 \mathrm{G} / \mathrm{G}^{80}$ \\
\hline & & & & & & NK V881 ${ }^{82}$ \\
\hline & & & & & & NAP131S ${ }^{82}$ \\
\hline CBR3 & & & & & & $\mathbf{N A}^{79}$ \\
\hline \multirow[t]{2}{*}{ CES1 } & NA $1440 \mathrm{~A}>\mathrm{T}^{115}$ & & & & & \\
\hline & NA $1525 \mathrm{~A}>\mathrm{C}^{115}$ & & & & & \\
\hline \multirow[t]{4}{*}{ CES2 } & NA $1647 \mathrm{C}>\mathrm{T}^{115}$ & & & & & \\
\hline & $\begin{array}{l}\text { NA *1: } \\
803 C>G, 8721 G>A, 9938 G>A, 9943 C>A^{104}\end{array}$ & & & & & \\
\hline & $N^{*} * 2: 8721 G>A^{104}$ & & & & & \\
\hline & $\begin{array}{l}\text { NA *3: } 8721 G>A, 9607 C>T, 9624 A>G \\
9938 G>A, 9943 C>A \\
104\end{array}$ & & & & & \\
\hline
\end{tabular}


Table 3 (continued)

\begin{tabular}{|c|c|c|c|c|c|c|}
\hline & \multicolumn{6}{|c|}{ TOXICITY } \\
\hline & IRINOTECAN & VINCRISTINE & CISPLATIN & MELPHALAN & ETOPOSIDE & DOXORUBICIN \\
\hline \multirow[t]{6}{*}{ CES2 } & NA *4: 8721G $>A, 9938 G>A, 9943 C>A^{104}$ & & & & & \\
\hline & NA *7: $4595 T>C^{104}$ & & & & & \\
\hline & NA *8: $7339 G>A^{104}$ & & & & & \\
\hline & NA *10: $1216 \mathrm{~T}>\mathrm{C}, 9938 \mathrm{G}>\mathrm{A}, 9943 \mathrm{C}>\mathrm{A}^{104}$ & & & & & \\
\hline & NA Haplotype 50-UTR-363, Intron $1+1361^{123}$ & & & & & \\
\hline & $\begin{array}{l}\text { NA Haplotype 50-UTR-363, Intron } 1+947 \text {, } \\
\text { Intron } 1+1361, \text { Intron } 1+1643^{123}\end{array}$ & & & & & \\
\hline VDR & & & & & NK & \\
\hline \multirow[t]{5}{*}{ MDR1 } & & NA C3435T ${ }^{62}$ & NK & & G571A $\mathrm{A}^{72}$ & NA G571A \\
\hline & & NA G2677T 62 & & & $\begin{array}{l}\text { NK } 3435 \\
\mathrm{C} / \mathrm{C}^{77,78}\end{array}$ & NK G1199A 83 \\
\hline & & NK G1199A ${ }^{71}$ & & & NK $2677 \mathrm{G} / \mathrm{G}^{77}$ & NA G1199A ${ }^{71}$ \\
\hline & & G571A $\mathrm{A}^{72}$ & & & NA G2677T ${ }^{78}$ & NK G1199T ${ }^{83}$ \\
\hline & & NK G1199T ${ }^{83}$ & & & $\begin{array}{l}\text { NK Haplotype } \\
2677 G-3435 C^{78}\end{array}$ & \\
\hline MRP1 & & & NK & & & $\begin{array}{l}\text { Aly671Val } \\
\mathrm{G} / \mathrm{T}, \mathrm{T} / \mathrm{T}^{81}\end{array}$ \\
\hline MRP2 & & & NK & & & $\begin{array}{l}\text { haplotype } \\
\text { Val1188Glu- } \\
\text { Cys1515Tyr }\end{array}$ \\
\hline \multirow[t]{6}{*}{ ABCB1(MDR1) } & $\begin{array}{l}\text { NA Haplotype: } 1236 \mathrm{C}>\mathrm{T}, 2677 \mathrm{G}>\mathrm{T} \\
\text { and } 3435 \mathrm{C}>\mathrm{T}{ }^{119}\end{array}$ & NA $893-$ Ser $^{63}$ & & & & \\
\hline & NA $1236 C>T^{92,115,116,124}$ & NA 893-Thr ${ }^{63}$ & & & & \\
\hline & NA $2677 G>T / A^{92,115,116,124}$ & & & & & \\
\hline & NA $3435 \mathrm{C}>\mathrm{T}^{88,92,115,116,121,124}$ & & & & & \\
\hline & $2677 \mathrm{G} / \mathrm{G}^{92}$ & & & & & \\
\hline & $3435 \mathrm{~T} / \mathrm{T}^{92}$ & & & & & \\
\hline \multirow[t]{3}{*}{ ABCC1(MRP1) } & NA $462 C>T^{115}$ & & & & & \\
\hline & NA $14008 G>A^{115}$ & & & & & \\
\hline & NA $34215 C>G^{115}$ & & & & & \\
\hline \multirow[t]{6}{*}{$\mathrm{ABCC} 2$} & NA $-24 \mathrm{~T}>\mathrm{C}^{92,124}$ & & & & & \\
\hline & NA $3972 T>C^{86}$ & & & & & \\
\hline & NA $33449 T>C^{115}$ & & & & & \\
\hline & NA $156231 A>G^{124}$ & & & & & \\
\hline & $* 2^{91}$ & & & & & \\
\hline & NA $1249 G>A, 3972 C>T^{92}$ & & & & & \\
\hline \multirow[t]{9}{*}{ ABCG2 } & NA $-19572-19576^{86,124}$ & & & & & \\
\hline & NA $-19202 G>C^{124}$ & & & & & \\
\hline & NA $-18845 \mathrm{~T}>\mathrm{C}^{124}$ & & & & & \\
\hline & NA -18604 delA ${ }^{124}$ & & & & & \\
\hline & NA 34G > $A^{92,124}$ & & & & & \\
\hline & NA $376 C>T^{124}$ & & & & & \\
\hline & NA $421 C>A^{86,89,92,105,124}$ & & & & & \\
\hline & NA $623 T>C^{115}$ & & & & & \\
\hline & NA $1444 A>G, 1445 G>C^{124}$ & & & & & \\
\hline ATP7A & & & NK & & & \\
\hline ATP7B & & & NK & & & \\
\hline CTR1 & & & NK & & & \\
\hline LAT1/LAT2 & & & & $\mathrm{NA}^{74,75}$ & & \\
\hline hOCT2 & & & NA $^{64}$ & & & \\
\hline \multirow[t]{2}{*}{ SLC22A16 } & & & & & & NK c. $146 \mathrm{G} / \mathrm{G}^{84}$ \\
\hline & & & & & & NA c. $755 T>C^{84}$ \\
\hline CyclinD1/D2/D3 & & & NK & & & \\
\hline
\end{tabular}


Table 4 Influence of pharmacogenetics on the pharmacokinetic profile of drugs in clinical development

\begin{tabular}{|c|c|c|c|c|c|c|c|}
\hline & \multicolumn{7}{|c|}{ EXPOSURE } \\
\hline & 17AAG & APREPITANT & BMS-536924 & EFLORNITHINE & IMATINIB & NUTLIN3 & ONCOLYTIC VIRUS \\
\hline CYP1A2 & & NK & & & NK & & \\
\hline CYP2C9 & & & & & NA $^{99}$ & & \\
\hline CYP2C19 & & NK & & & NA $^{99}$ & & \\
\hline CYP2D6 & & & & & NA $2 \mathrm{D}_{6} 4^{99}$ & & \\
\hline CYP3A4 & NK & NK & & & NA $^{99}$ & & \\
\hline CYP3A5 & $\begin{array}{l}\text { \$ } 3 A 5^{*} 3 \\
\text { (homozygous) } 96\end{array}$ & & & & NA $^{99,100}$ & & \\
\hline ABCB1 (Pgp) & & & & & NA $^{99}$ & NK & \\
\hline & & & & & $1236 \mathrm{TT}^{100}$ & & \\
\hline & & & & & $2677 \mathrm{TT}^{100}$ & & \\
\hline & & & & & $3435 T T^{100}$ & & \\
\hline ABCG2 & & & & & NA $^{99}$ & & \\
\hline NQ01 & NA NQO $1^{*} 2^{96}$ & & & & & & \\
\hline
\end{tabular}

* "A" indicates an increase in drug exposure, efficacy or toxicity;

$\dagger$ " indicates a decrease in drug exposure, efficacy or toxicity;

\$ "NA" indicates that there is no association between the corresponding gene and the pharmacokinetics of the drug;

$\S$ "NK" (Not Known) indicates that pharmacogenetic data have not been found in the published literature;

|| "grey cells" indicate the gene is not related to the pharmacokinetics of the drug.

Table 5 Influence of pharmacogenetics on the efficacy of drugs in clinical development

\begin{tabular}{|c|c|c|c|c|c|c|c|}
\hline & \multicolumn{7}{|c|}{ EFFICACY } \\
\hline & 17AAG & APREPITANT & BMS-536924 & EFLORNITHINE & IMATINIB & NUTLIN3 & ONCOLYTIC VIRUS \\
\hline CYP1A2 & & NK & & & NK & & \\
\hline CYP2C9 & & & & & NA $^{99}$ & & \\
\hline CYP2C19 & & NK & & & NA $^{99}$ & & \\
\hline CYP2D6 & & & & & NA $2 \mathrm{D} 6 * 4^{99}$ & & \\
\hline CYP3A4 & NK & NK & & & NA $^{99}$ & & \\
\hline CYP3A5 & NA $3 A 5^{\star} 3^{96}$ & & & & NA ${ }^{99,100}$ & & \\
\hline ABCB1 (Pgp) & & & & & NA $^{99}$ & NK & \\
\hline & & & & & NA 1236 TT $^{100}$ & & \\
\hline & & & & & NA 2677 TT $^{100}$ & & \\
\hline & & & & & NA 3435 TT $^{100}$ & & \\
\hline ABCG2 & & & & & NA ${ }^{99}$ & & \\
\hline NQ01 & NQO1*2 $2^{95,96,97,98}$ & & & & & & \\
\hline
\end{tabular}

* “业” indicates an increase in drug exposure, efficacy or toxicity;

$\dagger$ " $"$ " indicates a decrease in drug exposure, efficacy or toxicity;

\$ "NA" indicates that there is no association between the corresponding gene and the pharmacokinetics of the drug;

$\S$ "NK" (Not Known) indicates that pharmacogenetic data have not been found in the published literature;

|| "grey cells" indicate that the gene is not related to the pharmacokinetics of the drug.

Table 6 Influence of pharmacogenetics on the toxicity of drugs in clinical development

\begin{tabular}{|c|c|c|c|c|c|c|c|}
\hline & \multicolumn{7}{|c|}{ TOXICITY } \\
\hline & 17AAG & APREPITANT & BMS-536924 & EFLORNITHINE & IMATINIB & NUTLIN3 & ONCOLYTIC VIRUS \\
\hline CYP1A2 & & NK & & & NK & & \\
\hline CYP2C9 & & & & & NA $^{99}$ & & \\
\hline CYP2C19 & & NK & & & NA $^{99}$ & & \\
\hline CYP2D6 & & & & & NA $2 D 6^{*} 4^{99}$ & & \\
\hline CYP3A4 & NK & NK & & & NA 99 & & \\
\hline CYP3A5 & NA $3 A 5^{*} 3^{96}$ & & & & NA $^{99,100}$ & & \\
\hline ABCB1 (Pgp) & & & & & NA ${ }^{99}$ & NK & \\
\hline & & & & & NA 1236 TT $^{100}$ & & \\
\hline & & & & & NA 2677 TT $^{100}$ & & \\
\hline & & & & & NA 3435 TT $^{100}$ & & \\
\hline ABCG2 & & & & & NA 99 & & \\
\hline NQO1 & NA NQO ${ }^{*} 2^{96}$ & & & & & & \\
\hline
\end{tabular}

* "N" indicates an increase in drug exposure, efficacy or toxicity;

$\dagger$ " $=$ " indicates a decrease in drug exposure, efficacy or toxicity;

f "NA" indicates that there is no association between the corresponding gene and the pharmacokinetics of the drug;

§ "NK" (Not Known) indicates that pharmacogenetic data have not been found in the published literature;

|| "grey cells" indicate that the gene is not related to the pharmacokinetics of the drug. 


\section{References}

1. Maris JM, Hogarty MD, Bagatell R et al (2007) Neuroblastoma. Lancet 369:2106-2120

2. Maris JM (2005) The biologic basis for neuroblastoma heterogeneity and risk stratification. Curr Opin Pediatr 17:7-13

3. Park JR, Eggert A, Caron H (2008) Neuroblastoma: biology, prognosis, and treatment. Pediatr Clin N Am 55:97-120, x

4. Schramm A, Schulte JH, Klein-Hitpass L et al (2005) Prediction of clinical outcome and biological characterization of neuroblastoma by expression profiling. Oncogene 24:7902-7912

5. Mora J, Gerald WL, Cheung NK (2003) Evolving significance of prognostic markers associated with new treatment strategies in neuroblastoma. Cancer Lett 197:119-124

6. Castel V, Grau E, Noguera R et al (2007) Molecular biology of neuroblastoma. Clin Transl Oncol 9:478-483

7. Fischer M, Spitz R, Oberthur A et al (2008) Risk estimation of neuroblastoma patients using molecular markers. Klin Pädiatr 220:137-146

8. Krekels EH, van den Anker JN, Baiardi P et al (2007) Pharmacogenetics and paediatric drug development: issues and consequences to labelling and dosing recommendations. Expert Opin Pharmacother 8:1787-1799

9. Pruthi S, Boughey JC, Brandt KR et al (2007) A multidisciplinary approach to the management of breast cancer, part 2: therapeutic considerations. Mayo Clin Proc 82:1131-1140

10. Yan L, Hsu K, Beckman RA (2008) Antibody-based therapy for solid tumors. Cancer J 14:178-183

11. Gardiner SJ, Begg EJ (2006) Pharmacogenetics, drug-metabolizing enzymes, and clinical practice. Pharmacol Rev 58:521-590

12. Hedgecoe A, Martin P (2003) The drugs don't work: expectations and the shaping of pharmacogenetics. Soc Stud Sci $33: 327-364$

13. Groninger E, Meeuwsen-de Boer T, Koopmans P et al (2005) Vincristine pharmacokinetics and response to vincristine monotherapy in an up-front window study of the Dutch Childhood Leukaemia Study Group (DCLSG). Eur J Cancer 41:98-103

14. Gidding CE, Meeuwsen-de Boer GJ, Koopmans P et al (1999) Vincristine pharmacokinetics after repetitive dosing in children. Cancer Chemother Pharmacol 44:203-209

15. Frost BM, Lonnerholm G, Koopmans P et al (2003) Vincristine in childhood leukaemia: no pharmacokinetic rationale for dose reduction in adolescents. Acta Paediatr 92:551-557

16. De Bernardi B, Nicolas B, Boni L et al (2003) Disseminated neuroblastoma in children older than one year at diagnosis: comparable results with three consecutive high-dose protocols adopted by the Italian Co-Operative Group for Neuroblastoma. J Clin Oncol 21:1592-1601

17. Groninger E, Meeuwsen-de Boar T, Koopmans P et al (2002) Pharmacokinetics of vincristine monotherapy in childhood acute lymphoblastic leukemia. Pediatr Res 52:113-118

18. Lonnerholm G, Frost BM, Abrahamsson J et al (2008) Vincristine pharmacokinetics is related to clinical outcome in children with standard risk acute lymphoblastic leukemia. Br J Haematol 142:616-621

19. Kushner BH, Kramer K, LaQuaglia MP et al (2004) Reduction from seven to five cycles of intensive induction chemotherapy in children with high-risk neuroblastoma. J Clin Oncol 22:4888-4892

20. Coze C, Hartmann O, Michon J et al (1997) NB87 induction protocol for stage 4 neuroblastoma in children over 1 year of age: a report from the French Society of Pediatric Oncology. J Clin Oncol 15:3433-3440

21. Garaventa A, Luksch R, Biasotti S et al (2003) A phase II study of topotecan with vincristine and doxorubicin in children with recurrent/refractory neuroblastoma. Cancer 98:2488-2494
22. Valteau-Couanet D, Michon J, Boneu A et al (2005) Results of induction chemotherapy in children older than 1 year with a stage 4 neuroblastoma treated with the NB 97 French Society of Pediatric Oncology (SFOP) protocol. J Clin Oncol 23:532-540

23. Lanvers-Kaminsky C, Krefeld B, Dinnesen AG et al (2006) Continuous or repeated prolonged cisplatin infusions in children: a prospective study on ototoxicity, platinum concentrations, and standard serum parameters. Pediatr Blood Cancer 47:183-193

24. Mastrangelo R, Tornesello A, Lasorella A et al (1997) Optimal use of the 131-I-metaiodobenzylguanidine and cisplatin combination in advanced neuroblastoma. J Neurooncol 31:153-158

25. Souid AK, Dubowy RL, Blaney SM et al (2003) Phase I clinical and pharmacologic study of weekly cisplatin and irinotecan combined with amifostine for refractory solid tumors. Clin Cancer Res 9:703-710

26. Kushner BH, Budnick A, Kramer K et al (2006) Ototoxicity from high-dose use of platinum compounds in patients with neuroblastoma. Cancer 107:417-422

27. Kaneko M, Tsuchida Y, Mugishima H et al (2002) Intensified chemotherapy increases the survival rates in patients with stage 4 neuroblastoma with MYCN amplification. J Pediatr Hematol Oncol 24:613-621

28. Nath CE, Shaw PJ, Montgomery K et al (2005) Melphalan pharmacokinetics in children with malignant disease: influence of body weight, renal function, carboplatin therapy and total body irradiation. Br J Clin Pharmacol 59:314-324

29. Nath CE, Shaw PJ, Montgomery K et al (2007) Population pharmacokinetics of melphalan in paediatric blood or marrow transplant recipients. Br J Clin Pharmacol 64:151-164

30. Vassal G, Tranchand B, Valteau-Couanet D et al (2001) Pharmacodynamics of tandem high-dose melphalan with peripheral blood stem cell transplantation in children with neuroblastoma and medulloblastoma. Bone Marrow Transplant 27:471-477

31. Nieto Y, Vaughan WP (2004) Pharmacokinetics of high-dose chemotherapy. Bone Marrow Transplant 33:259-269

32. Canete A, Gerrard M, Rubie H et al (2009) Poor survival for infants with MYCN-amplified metastatic neuroblastoma despite intensified treatment: the International Society of Paediatric Oncology European Neuroblastoma experience. J Clin Oncol 27:1014-1019

33. Diaz MA, Vicent MG, Madero L (1999) High-dose busulfan/ melphalan as conditioning for autologous PBPC transplantation in pediatric patients with solid tumors. Bone Marrow Transplant 24:1157-1159

34. Hartmann O, Valteau-Couanet D, Benhamou E et al (1997) Stage IV neuroblastoma in patients over 1 year of age at diagnosis: consolidation of poor responders with combined busulfan, cyclophosphamide and melphalan followed by in vitro mafosfamide-purged autologous bone marrow transplantation. Eur J Cancer 33:2126-2129

35. Pritchard J, Cotterill SJ, Germond SM et al (2005) High dose melphalan in the treatment of advanced neuroblastoma: results of a randomised trial (ENSG-1) by the European Neuroblastoma Study Group. Pediatr Blood Cancer 44:348-357

36. Eksborg S, Soderhall S, Frostvik-Stolt M et al (2000) Plasma pharmacokinetics of etoposide (VP-16) after i.v. administration to children. Anticancer Drugs 11:237-241

37. Kato Y, Nishimura S, Sakura N et al (2003) Pharmacokinetics of etoposide with intravenous drug administration in children and adolescents. Pediatr Int 45:74-79

38. Wurthwein G, Klingebiel T, Krumpelmann S et al (2002) Population pharmacokinetics of high-dose etoposide in children receiving different conditioning regimens. Anticancer Drugs 13:101-110

39. Davidson A, Gowing R, Lowis S et al (1997) Phase II study of 21 day schedule oral etoposide in children. New agents group of 
the United Kingdom children's cancer study group (UKCCSG). Eur J Cancer 33:1816-1822

40. Lowis SP, Pearson AD, Newell DR et al (1993) Etoposide pharmacokinetics in children: the development and prospective validation of a dosing equation. Cancer Res 53:4881-4889

41. Mross K, Reifke J, Bewermeier P et al (1996) The pharmacokinetics and toxicity of two application schedules with high-dose VP-16 in patients receiving an allogeneic bone marrow transplantation. Ann Oncol 7:83-88

42. Palle J, Britt-Marie F, Goran G et al (2006) Etoposide pharmacokinetics in children treated for acute myeloid leukemia. Anticancer Drugs 17:1087-1094

43. Kushner BH, Kramer K, Cheung NK (1999) Oral etoposide for refractory and relapsed neuroblastoma. J Clin Oncol 17:3221-3225

44. Simon T, Langler A, Harnischmacher U et al (2007) Topotecan, cyclophosphamide, and etoposide (TCE) in the treatment of high-risk neuroblastoma. Results of a phase-II trial. J Cancer Res Clin Oncol 133:653-661

45. Simon T, Langler A, Berthold F et al (2007) Topotecan and etoposide in the treatment of relapsed high-risk neuroblastoma: results of a phase 2 trial. J Pediatr Hematol Oncol 29:101-106

46. Frost BM, Eksborg S, Bjork O et al (2002) Pharmacokinetics of doxorubicin in children with acute lymphoblastic leukemia: multi-institutional collaborative study. Med Pediatr Oncol 38:329-337

47. Hempel G, Flege S, Wurthwein G et al (2002) Peak plasma concentrations of doxorubicin in children with acute lymphoblastic leukemia or non-Hodgkin lymphoma. Cancer Chemother Pharmacol 49:133-141

48. Palle J, Frost BM, Peterson C et al (2006) Doxorubicin pharmacokinetics is correlated to the effect of induction therapy in children with acute myeloid leukemia. Anticancer Drugs 17:385-392

49. Mugishima H, Matsunaga T, Yagi K et al (2002) Phase I study of irinotecan in pediatric patients with malignant solid tumors. $\mathrm{J}$ Pediatr Hematol Oncol 24:94-100

50. Vassal G, Doz F, Frappaz D et al (2003) A phase I study of irinotecan as a 3-week schedule in children with refractory or recurrent solid tumors. J Clin Oncol 21:3844-3852

51. Rodriguez-Galindo C, Crews KR, Stewart CF et al (2006) Phase I study of the combination of topotecan and irinotecan in children with refractory solid tumors. Cancer Chemother Pharmacol 57:15-24

52. Bomgaars L, Kerr J, Berg S et al (2006) A phase I study of irinotecan administered on a weekly schedule in pediatric patients. Pediatr Blood Cancer 46:50-55

53. Levy AS, Meyers PA, Wexler LH et al (2009) Phase 1 and pharmacokinetic study of concurrent carboplatin and irinotecan in subjects aged 1 to 21 years with refractory solid tumors. Cancer 115:207-216

54. Gore L, Chawla S, Petrilli A et al (2009) Aprepitant in adolescent patients for prevention of chemotherapy-induced nausea and vomiting: a randomized, double-blind, placebocontrolled study of efficacy and tolerability. Pediatr Blood Cancer 52:242-247

55. Weigel BJ, Blaney SM, Reid JM et al (2007) A phase I study of 17-allylaminogeldanamycin in relapsed/refractory pediatric patients with solid tumors: a children's oncology group study. Clin Cancer Res 13:1789-1793

56. Bagatell R, Gore L, Egorin MJ et al (2007) Phase I pharmacokinetic and pharmacodynamic study of 17-N-allylamino-17demethoxygeldanamycin in pediatric patients with recurrent or refractory solid tumors: a pediatric oncology experimental therapeutics investigators consortium study. Clin Cancer Res 13:1783-1788

57. Bond M, Bernstein ML, Pappo A et al (2008) A phase II study of imatinib mesylate in children with refractory or relapsed solid tumors: a children's oncology group study. Pediatr Blood Cancer 50:254-258

58. Marangon E, Citterio M, Sala F et al (2009) Pharmacokinetic profile of imatinib mesylate and N-desmethyl-imatinib (CGP 74588 ) in children with newly diagnosed $\mathrm{Ph}+$ acute leukemias. Cancer Chemother Pharmacol 63:563-566

59. Pollack IF, Jakacki RI, Blaney SM et al (2007) Phase I trial of imatinib in children with newly diagnosed brainstem and recurrent malignant gliomas: a pediatric brain tumor consortium report. Neuro Oncol 9:145-160

60. Dennison JB, Jones DR, Renbarger JL et al (2007) Effect of CYP3A5 expression on vincristine metabolism with human liver microsomes. J Pharmacol Exp Ther 321:553-563

61. Plasschaert SL, Groninger E, Boezen M et al (2004) Influence of functional polymorphisms of the MDR1 gene on vincristine pharmacokinetics in childhood acute lymphoblastic leukemia. Clin Pharmacol Ther 76:220-229

62. Schaefer M, Roots I, Gerloff T (2006) In-vitro transport characteristics discriminate wild-type ABCB1 (MDR1) from ALA893SER and ALA893THR polymorphisms. Pharmacogenet Genomics 16:855-861

63. Filipski KK, Loos WJ, Verweij J et al (2008) Interaction of Cisplatin with the human organic cation transporter 2. Clin Cancer Res 14:3875-3880

64. Oldenburg J, Fossa SD, Ikdahl T (2008) Genetic variants associated with cisplatin-induced ototoxicity. Pharmacogenomics 9:1521-1530

65. Rabik CA, Dolan ME (2007) Molecular mechanisms of resistance and toxicity associated with platinating agents. Cancer Treat Rev 33:9-23

66. Zhang L, Plon SE, Nuchtern JG et al (2004) Cyclin D and cisplatin cytotoxicity in primary neuroblastoma cell lines. Anticancer Drugs 15:883-888

67. de Cremoux P, Jourdan-Da-Silva N, Couturier J et al (2007) Role of chemotherapy resistance genes in outcome of neuroblastoma. Pediatr Blood Cancer 48:311-317

68. Renbarger JL, McCammack KC, Rouse CE et al (2008) Effect of race on vincristine-associated neurotoxicity in pediatric acute lymphoblastic leukemia patients. Pediatr Blood Cancer 50:769-771

69. Dennison JB, Kulanthaivel P, Barbuch RJ et al (2006) Selective metabolism of vincristine in vitro by CYP3A5. Drug Metab Dispos 34:1317-1327

70. Woodahl EL, Crouthamel MH, Bui T, et al. (2009) MDR1 (ABCB1) G1199A (Ser400Asn) polymorphism alters transepithelial permeability and sensitivity to anticancer agents. Cancer Chemother Pharmacol

71. Yang Z, Wu D, Bui T et al (2008) A novel human multidrug resistance gene MDR1 variant G571A (G191R) modulates cancer drug resistance and efflux transport. J Pharmacol Exp Ther 327:474-481

72. Oldenburg J, Kraggerud SM, Cvancarova M et al (2007) Cisplatin-induced long-term hearing impairment is associated with specific glutathione s-transferase genotypes in testicular cancer survivors. J Clin Oncol 25:708-714

73. del Amo EM, Urtti A, Yliperttula M (2008) Pharmacokinetic role of L-type amino acid transporters LAT1 and LAT2. Eur J Pharm Sci 35:161-174

74. Kuhne A, Kaiser R, Schirmer M et al (2007) Genetic polymorphisms in the amino acid transporters LAT1 and LAT2 in relation to the pharmacokinetics and side effects of melphalan. Pharmacogenet Genomics 17:505-517

75. van Schaik RH (2008) CYP450 pharmacogenetics for personalizing cancer therapy. Drug Resist Updat 11:77-98

76. Kishi S, Yang W, Boureau B et al (2004) Effects of prednisone and genetic polymorphisms on etoposide disposition in children with acute lymphoblastic leukemia. Blood 103:67-72 
77. Sohn JW, Lee SY, Lee SJ et al (2006) MDR1 polymorphisms predict the response to etoposide-cisplatin combination chemotherapy in small cell lung cancer. Jpn J Clin Oncol 36:137-141

78. Lal S, Sandanaraj E, Wong ZW et al (2008) CBR1 and CBR3 pharmacogenetics and their influence on doxorubicin disposition in Asian breast cancer patients. Cancer Sci 99:2045-2054

79. Gonzalez-Covarrubias V, Zhang J, Kalabus JL et al (2009) Pharmacogenetics of human carbonyl reductase 1 (CBR1) in livers from black and white donors. Drug Metab Dispos 37: 400-407

80. Wojnowski L, Kulle B, Schirmer M et al (2005) NAD(P)H oxidase and multidrug resistance protein genetic polymorphisms are associated with doxorubicin-induced cardiotoxicity. Circulation 112:3754-3762

81. Bains OS, Karkling MJ, Grigliatti TA, et al. (2009) Two nonsynonymous single nucleotide polymorphisms of human carbonyl reductase 1 demonstrate reduced in vitro metabolism of daunorubicin and doxorubicin. Drug Metab Dispos

82. Crouthamel MH, Wu D, Yang Z et al (2006) A novel MDR1 G1199T variant alters drug resistance and efflux transport activity of P-glycoprotein in recombinant Hek cells. J Pharm Sci 95:2767-2777

83. Lal S, Wong ZW, Jada SR et al (2007) Novel SLC22A16 polymorphisms and influence on doxorubicin pharmacokinetics in Asian breast cancer patients. Pharmacogenomics 8:567-575

84. Mossallam GI (2006) Abdel Hamid TM, Samra MA: Glutathione S-transferase GSTM1 and GSTT1 polymorphisms in adult acute myeloid leukemia; its impact on toxicity and response to chemotherapy. J Egypt Natl Canc Inst 18:264-273

85. Smith NF, Figg WD, Sparreboom A (2006) Pharmacogenetics of irinotecan metabolism and transport: an update. Toxicol In Vitro 20:163-175

86. Araki K, Fujita K, Ando Y et al (2006) Pharmacogenetic impact of polymorphisms in the coding region of the UGT1A1 gene on SN-38 glucuronidation in Japanese patients with cancer. Cancer Sci 97:1255-1259

87. Cote JF, Kirzin S, Kramar A et al (2007) UGT1A1 polymorphism can predict hematologic toxicity in patients treated with irinotecan. Clin Cancer Res 13:3269-3275

88. Jada SR, Lim R, Wong CI et al (2007) Role of UGT1A1*6, $\mathrm{UGT} 1 \mathrm{~A} 1 * 28$ and $\mathrm{ABCG} 2$ c. $421 \mathrm{C}>\mathrm{A}$ polymorphisms in irinotecan-induced neutropenia in Asian cancer patients. Cancer Sci 98:1461-1467

89. Minami H, Sai K, Saeki M et al (2007) Irinotecan pharmacokinetics/ pharmacodynamics and UGT1A genetic polymorphisms in Japanese: roles of UGT1A $1 * 6$ and $* 28$. Pharmacogenet Genomics 17:497-504

90. de Jong FA, Scott-Horton TJ, Kroetz DL et al (2007) Irinotecaninduced diarrhea: functional significance of the polymorphic ABCC2 transporter protein. Clin Pharmacol Ther 81:42-49

91. Han JY, Lim HS, Yoo YK et al (2007) Associations of ABCB1, $\mathrm{ABCC} 2$, and $\mathrm{ABCG} 2$ polymorphisms with irinotecanpharmacokinetics and clinical outcome in patients with advanced non-small cell lung cancer. Cancer 110:138-147

92. Sai K, Saito Y, Fukushima-Uesaka H et al (2008) Impact of CYP3A4 haplotypes on irinotecan pharmacokinetics in Japanese cancer patients. Cancer Chemother Pharmacol 62:529-537

93. Bomgaars LR, Bernstein M, Krailo M et al (2007) Phase II trial of irinotecan in children with refractory solid tumors: a children's oncology group study. J Clin Oncol 25:4622-4627

94. Gaspar N, Sharp SY, Pacey S et al (2009) Acquired resistance to 17-allylamino-17-demethoxygeldanamycin (17-AAG, tanespimycin) in glioblastoma cells. Cancer Res 69:1966-1975

95. Goetz MP, Toft D, Reid J et al (2005) Phase I trial of 17allylamino-17-demethoxygeldanamycin in patients with advanced cancer. J Clin Oncol 23:1078-1087
96. Guo W, Reigan P, Siegel D et al (2005) Formation of 17-allylaminodemethoxygeldanamycin (17-AAG) hydroquinone by $\mathrm{NAD}(\mathrm{P}) \mathrm{H}$ : quinone oxidoreductase 1: role of 17-AAG hydroquinone in heat shock protein 90 inhibition. Cancer Res 65:10006-10015

97. Kelland LR, Sharp SY, Rogers PM et al (1999) DT-Diaphorase expression and tumor cell sensitivity to 17-allylamino, 17demethoxygeldanamycin, an inhibitor of heat shock protein 90 . J Natl Cancer Inst 91:1940-1949

98. Gardner ER, Burger H, van Schaik RH et al (2006) Association of enzyme and transporter genotypes with the pharmacokinetics of imatinib. Clin Pharmacol Ther 80:192-201

99. Gurney H, Wong M, Balleine RL et al (2007) Imatinib disposition and ABCB1 (MDR1, P-glycoprotein) genotype. Clin Pharmacol Ther 82:33-40

100. Ando Y, Saka H, Ando M et al (2000) Polymorphisms of UDPglucuronosyltransferase gene and irinotecan toxicity: a pharmacogenetic analysis. Cancer Res 60:6921-6926

101. Ando Y, Ueoka H, Sugiyama T et al (2002) Polymorphisms of UDP-glucuronosyltransferase and pharmacokinetics of irinotecan. Ther Drug Monit 24:111-116

102. Carlini LE, Meropol NJ, Bever J et al (2005) UGT1A7 and UGT1A9 polymorphisms predict response and toxicity in colorectal cancer patients treated with capecitabine/irinotecan. Clin Cancer Res 11:1226-1236

103. Charasson V, Bellott R, Meynard D et al (2004) Pharmacogenetics of human carboxylesterase 2, an enzyme involved in the activation of irinotecan into SN-38. Clin Pharmacol Ther $76: 528-535$

104. de Jong FA, Marsh S, Mathijssen RH et al (2004) ABCG2 pharmacogenetics: ethnic differences in allele frequency and assessment of influence on irinotecan disposition. Clin Cancer Res 10:5889-5894

105. Font A, Sanchez JM, Taron M et al (2003) Weekly regimen of irinotecan/docetaxel in previously treated non-small cell lung cancer patients and correlation with uridine diphosphate glucuronosyltransferase 1A1 (UGT1A1) polymorphism. Investig New Drugs 21:435-443

106. Gagne JF, Montminy V, Belanger P et al (2002) Common human UGT1A polymorphisms and the altered metabolism of irinotecan active metabolite 7-ethyl-10-hydroxycamptothecin (SN-38). Mol Pharmacol 62:608-617

107. Innocenti F, Grimsley C, Das S et al (2002) Haplotype structure of the UDP-glucuronosyltransferase $1 \mathrm{~A} 1$ promoter in different ethnic groups. Pharmacogenetics 12:725-733

108. Innocenti F, Undevia SD, Iyer L et al (2004) Genetic variants in the UDP-glucuronosyltransferase $1 \mathrm{~A} 1$ gene predict the risk of severe neutropenia of irinotecan. J Clin Oncol 22:1382-1388

109. Iyer L, Hall D, Das S et al (1999) Phenotype-genotype correlation of in vitro SN-38 (active metabolite of irinotecan) and bilirubin glucuronidation in human liver tissue with UGT1A1 promoter polymorphism. Clin Pharmacol Ther 65:576-582

110. Jinno H, Tanaka-Kagawa T, Hanioka N et al (2003) Glucuronidation of 7-ethyl-10-hydroxycamptothecin (SN-38), an active metabolite of irinotecan (CPT-11), by human UGT1A1 variants, G71R, P229Q, and Y486D. Drug Metab Dispos 31:108-113

111. Jinno H, Saeki M, Saito Y et al (2003) Functional characterization of human UDP-glucuronosyltransferase 1A9 variant, D256N, found in Japanese cancer patients. J Pharmacol Exp Ther 306:688-693

112. Kaniwa N, Kurose K, Jinno H et al (2005) Racial variability in haplotype frequencies of UGT1A1 and glucuronidation activity of a novel single nucleotide polymorphism $686 \mathrm{C}>\mathrm{T}$ (P229L) found in an African-American. Drug Metab Dispos 33:458-465

113. Marcuello E, Altes A, Menoyo A et al (2004) UGT1A1 gene variations and irinotecan treatment in patients with metastatic colorectal cancer. Br J Cancer 91:678-682 
114. Mathijssen RH, Marsh S, Karlsson MO et al (2003) Irinotecan pathway genotype analysis to predict pharmacokinetics. Clin Cancer Res 9:3246-3253

115. Mathijssen RH, de Jong FA, van Schaik RH et al (2004) Prediction of irinotecan pharmacokinetics by use of cytochrome P450 3A4 phenotyping probes. J Natl Cancer Inst 96:1585-1592

116. Paoluzzi L, Singh AS, Price DK et al (2004) Influence of genetic variants in UGT1A1 and UGT1A9 on the in vivo glucuronidation of SN-38. J Clin Pharmacol 44:854-860

117. Rouits E, Boisdron-Celle M, Dumont A et al (2004) Relevance of different UGT1A1 polymorphisms in irinotecan-induced toxicity: a molecular and clinical study of 75 patients. Clin Cancer Res 10:5151-5159

118. Sai K, Kaniwa N, Itoda M et al (2003) Haplotype analysis of ABCB1/MDR1 blocks in a Japanese population reveals genotype-dependent renal clearance of irinotecan. Pharmacogenetics 13:741-757

119. Sai K, Saeki M, Saito Y et al (2004) UGT1A1 haplotypes associated with reduced glucuronidation and increased serum bilirubin in irinotecan-administered Japanese patients with cancer. Clin Pharmacol Ther 75:501-515

120. Soepenberg O, Dumez H, Verweij J et al (2005) Phase I pharmacokinetic, food effect, and pharmacogenetic study of oral irinotecan given as semisolid matrix capsules in patients with solid tumors. Clin Cancer Res 11:1504-1511

121. Villeneuve L, Girard H, Fortier LC et al (2003) Novel functional polymorphisms in the UGT1A7 and UGT1A9 glucuronidating enzymes in Caucasian and African-American subjects and their impact on the metabolism of 7-ethyl-10-hydroxycamptothecin and flavopiridol anticancer drugs. J Pharmacol Exp Ther 307:117-128

122. Wu MH, Chen P, Wu X et al (2004) Determination and analysis of single nucleotide polymorphisms and haplotype structure of the human carboxylesterase 2 gene. Pharmacogenetics 14:595-605

123. Zhou Q, Sparreboom A, Tan EH et al (2005) Pharmacogenetic profiling across the irinotecan pathway in Asian patients with cancer. Br J Clin Pharmacol 59:415-424

124. Kang J, Kamal A, Burrows FJ et al (2006) Inhibition of neuroblastoma xenograft growth by Hsp90 inhibitors. Anticancer Res 26:1903-1908

125. Jayanthan A, Fowler J, Hawkins L et al (2008) Effects of Hsp90 inhibition in neuroblastoma: analysis of drug sensitivity, target modulation and the influence of bone marrow microenvironment. J Exp Ther Oncol 7:183-193

126. Munoz M, Rosso M (2009) The NK-1 receptor antagonist aprepitant as a broad spectrum antitumor drug. Invest New Drugs

127. Huang F, Greer A, Hurlburt W et al (2009) The mechanisms of differential sensitivity to an insulin-like growth factor-1 receptor inhibitor (BMS-536924) and rationale for combining with EGFR/HER2 inhibitors. Cancer Res 69:161-170

128. Wallick CJ, Gamper I, Thorne M et al (2005) Key role for p27Kip1, retinoblastoma protein $\mathrm{Rb}$, and $\mathrm{MYCN}$ in polyamine inhibitor-induced G1 cell cycle arrest in MYCN-amplified human neuroblastoma cells. Oncogene 24:5606-5618

129. Hogarty MD, Norris MD, Davis K et al (2008) ODC1 is a critical determinant of MYCN oncogenesis and a therapeutic target in neuroblastoma. Cancer Res 68:9735-9745

130. Koomoa DL, Yco LP, Borsics T et al (2008) Ornithine decarboxylase inhibition by alpha-difluoromethylornithine activates opposing signaling pathways via phosphorylation of both Akt/protein kinase B and p27Kip1 in neuroblastoma. Cancer Res 68:9825-9831

131. Rounbehler RJ, Li W, Hall MA et al (2009) Targeting ornithine decarboxylase impairs development of MYCN-amplified neuroblastoma. Cancer Res 69:547-553
132. Beppu K, Jaboine J, Merchant MS et al (2004) Effect of imatinib mesylate on neuroblastoma tumorigenesis and vascular endothelial growth factor expression. J Natl Cancer Inst 96: 46-55

133. Rossler J, Zambrzycka I, Lagodny J et al (2006) Effect of STI571 (imatinib mesylate) in combination with retinoic acid and gamma-irradiation on viability of neuroblastoma cells. Biochem Biophys Res Commun 342:1405-1412

134. Palmberg E, Johnsen JI, Paulsson J et al (2009) Metronomic scheduling of imatinib abrogates clonogenicity of neuroblastoma cells and enhances their susceptibility to selected chemotherapeutic drugs in vitro and in vivo. Int $\mathrm{J}$ Cancer 124:1227-1234

135. Vitali R, Cesi V, Nicotra MR et al (2003) c-Kit is preferentially expressed in MYCN-amplified neuroblastoma and its effect on cell proliferation is inhibited in vitro by STI-571. Int J Cancer 106:147-152

136. Petain A, Kattygnarath D, Azard J et al (2008) Population pharmacokinetics and pharmacogenetics of imatinib in children and adults. Clin Cancer Res 14:7102-7109

137. Van Maerken T, Speleman F, Vermeulen J et al (2006) Smallmolecule MDM2 antagonists as a new therapy concept for neuroblastoma. Cancer Res 66:9646-9655

138. Ribas J, Boix J, Meijer L (2006) (R)-roscovitine (CYC202, Seliciclib) sensitizes SH-SY5Y neuroblastoma cells to nutlin-3induced apoptosis. Exp Cell Res 312:2394-2400

139. Becker K, Marchenko ND, Maurice M et al (2007) Hyperubiquitylation of wild-type p53 contributes to cytoplasmic sequestration in neuroblastoma. Cell Death Differ 14:1350 1360

140. Michaelis M, Rothweiler F, Klassert D et al (2009) Reversal of P-glycoprotein-mediated multidrug resistance by the murine double minute 2 antagonist nutlin-3. Cancer Res 69:416-421

141. Barbieri E, Mehta P, Chen Z et al (2006) MDM2 inhibition sensitizes neuroblastoma to chemotherapy-induced apoptotic cell death. Mol Cancer Ther 5:2358-2365

142. Aghi M, Martuza RL (2005) Oncolytic viral therapies - the clinical experience. Oncogene 24:7802-7816

143. Shen Y, Nemunaitis J (2006) Herpes simplex virus 1 (HSV-1) for cancer treatment. Cancer Gene Ther 13:975-992

144. Geoerger B, van Beusechem VW, Opolon P et al (2005) Expression of p53, or targeting towards EGFR, enhances the oncolytic potency of conditionally replicative adenovirus against neuroblastoma. J Gene Med 7:584-594

145. Toyoda H, Yin J, Mueller S et al (2007) Oncolytic treatment and cure of neuroblastoma by a novel attenuated poliovirus in a novel poliovirus-susceptible animal model. Cancer Res 67: 2857-2864

146. Mahller YY, Williams JP, Baird WH et al (2009) Neuroblastoma cell lines contain pluripotent tumor initiating cells that are susceptible to a targeted oncolytic virus. PLoS ONE 4:e4235

147. Ino Y, Saeki Y, Fukuhara $\mathrm{H}$ et al (2006) Triple combination of oncolytic herpes simplex virus-1 vectors armed with interleukin12 , interleukin-18, or soluble B7-1 results in enhanced antitumor efficacy. Clin Cancer Res 12:643-652

148. Mahller YY, Vaikunth SS, Ripberger MC et al (2008) Tissue inhibitor of metalloproteinase-3 via oncolytic herpesvirus inhibits tumor growth and vascular progenitors. Cancer Res 68:1170 1179

149. Parikh NS, Currier MA, Mahller YY et al (2005) Oncolytic herpes simplex virus mutants are more efficacious than wildtype adenovirus Type 5 for the treatment of high-risk neuroblastomas in preclinical models. Pediatr Blood Cancer 44:469478

150. Li H, Dutuor A, Tao L et al (2007) Virotherapy with a type 2 herpes simplex virus-derived oncolytic virus induces potent 
antitumor immunity against neuroblastoma. Clin Cancer Res $13: 316-322$

151. Thomas SK, Messam CA, Spengler BA et al (2004) Nestin is a potential mediator of malignancy in human neuroblastoma cells. J Biol Chem 279:27994-27999

152. Korja M, Finne J, Salmi TT et al (2005) Chromogenic in situ hybridization-detected hotspot MYCN amplification associates with Ki-67 expression and inversely with nestin expression in neuroblastomas. Mod Pathol 18:1599-1605

153. Breimer DD (2008) PK/PD modelling and beyond: impact on drug development. Pharm Res 25:2720-2722
154. Zhang L, Sinha V, Forgue ST et al (2006) Model-based drug development: the road to quantitative pharmacology. J Pharmacokinet Pharmacodyn 33:369-393

155. Derendorf H, Lesko LJ, Chaikin P et al (2000) Pharmacokinetic/ pharmacodynamic modeling in drug research and development. J Clin Pharmacol 40:1399-1418

156. Miller R, Ewy W, Corrigan BW et al (2005) How modeling and simulation have enhanced decision making in new drug development. J Pharmacokinet Pharmacodyn 32:185-197

157. Rajman I (2008) PK/PD modelling and simulations: utility in drug development. Drug Discov Today 13:341-346 